\title{
PROCESSOS FLUVIAIS NO RIO AMAZONAS: EROSÃO LATERAL E IMPLICAÇÕES PARA A CIDADE DE PARINTINS
}

\author{
River processes in the Amazon river: lateral erosion and implications for the \\ city of Parintins
}

\author{
Rildo Oliveira Marques \\ Mestre em Geografia pela Universidade Federal do Amazonas - UFAM \\ rildomarques.geo@gmail.com \\ José Alberto Lima de Carvalho \\ Professor da Universidade Federal do Amazonas - UFAM \\ albertogeografo@gmail.com
}

\begin{abstract}
RESUMO: A erosão lateral dos canais resulta de processos que envolvem inúmeros fatores que atuam em conjunto dentro do canal fluvial. Na Amazônia brasileira, o complexo processo de erosão das margens do rio Amazonas, fenômeno conhecido regionalmente por terras caídas, tem afetado não apenas as populações dispersas ao longo de sua calha, mas também aglomerados como comunidades, vilas e cidades. $O$ presente trabalho teve como objetivo principal compreender o processo de erosão lateral do rio Amazonas em frente da cidade de Parintins e as implicações socioeconômicas desse fenômeno. A interpretação é de que o processo resulta da combinação de fatores como a forma e geometria do canal; pressão e as forças hidráulicas atuantes; composição granulométrica da margem; condições climáticas e ação antrópica. Destaca-se o fato de que as medições batimétricas revelaram que o talvegue do rio está a $328 \mathrm{~m}$ próximo da margem direita, cuja profundidade atinge $98 \mathrm{~m}$, o que facilita a erosão em profundidade e dificulta qualquer obra de engenharia para conter o processo. Quanto às implicações, destacamos o elevado custo financeiro para o município como construção de muros de arrimo e perda de ruas; desvalorização de propriedades com frente e/ou fundo para o rio; risco a circulação de veículos e à navegação e; dificuldade de embarque e desembarque durante a vazante.
\end{abstract}

Palavras-chave: geomorfologia fluvial; erosão de margem; implicações sociais.

\begin{abstract}
The lateral erosion of the channels results from processes that involve numerous factors that act together within the river channel. In the Brazilian Amazon, the complex process of erosion of the banks of the Amazon River, a phenomenon known regionally by fallen lands, has affected not only the dispersed populations along its channel, but also agglomerates such as village communities and cities. The present work had as main objective to understand the lateral erosion process of the Amazon river in front of the city of Parintins and the socioeconomic implications of this phenomenon. The interpretation is that the process results from the combination of factors such as the shape and geometry of the channel; pressure and hydraulic forces; composition of the margin; climatic conditions and anthropogenic action. It should be noted that the bathymetric measurements revealed that the river's thalweg is $328 \mathrm{~m}$ near the right margin, whose depth reaches $98 \mathrm{~m}$, which facilitates erosion in depth and hinders any engineering work to contain the process. Regarding the implications, we highlight the high financial cost for the municipality as construction of retaining walls and loss of streets; devaluation of properties with front and / or bottom for the river; risk of vehicle traffic and navigation; difficulty of embarkation and disembarkation during the ebb.
\end{abstract}

Keywords: fluvial geomorphology riverbank erosion; social implications.

\section{INTRODUÇÃO}

A erosão dos canais resulta de processos que envolvem inúmeros fatores que atuam em conjunto dentro do canal fluvial. A atual discussão sobre o tema apresenta diferentes conclusões, não havendo, portanto, consenso quanto aos mecanismos de 
PROCESSOS FLUVIAIS NO RIO AMAZONAS: EROSÃO LATERAL E IMPLICAÇÕES PARA A CIDADE DE PARINTINS

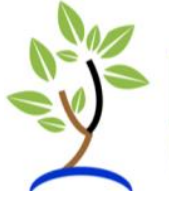

causa. Na Amazônia brasileira, o complexo processo de erosão das margens do rio Amazonas, fenômeno conhecido regionalmente por terras caídas, tem afetado não apenas as populações dispersas ao longo de sua calha, mas também aglomerados como comunidades, vilas e cidades. A capacidade desse fenômeno em transformar a paisagem já impressionava naturalistas, viajantes e cronistas, desde os primeiros séculos após a conquista e exploração da América.

$\mathrm{Na}$ cidade de Parintins o problema é notificado há algumas décadas, e tem seus primeiros registros no livro de Atas da 7ª Legislatura de vereadores (1973-1976) da Câmara Municipal. A preocupação do executivo e legislativo aumentou até que

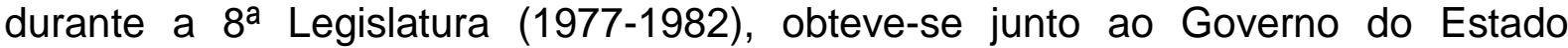
recursos para a construção de um muro de arrimo em um trecho em frente à cidade. Porém, durante as décadas seguintes, a pressão do rio Amazonas, associada às fortes chuvas e infiltrações das águas pluviais, fizeram com que a construção, além de comprometida, sofresse constante fraturamento e abalo.

Parintins localiza-se no extremo leste do Estado do Amazonas, num trecho côncavo da margem direita do rio Amazonas, sendo construída em um terraço baixo pertencente a um complexo sistema flúvio-lacustre da planície amazônica (figura 1). Pela sua posição, a mesma recebe o ataque quase frontal do rio Amazonas, comprometendo assim o trecho em frente à cidade.

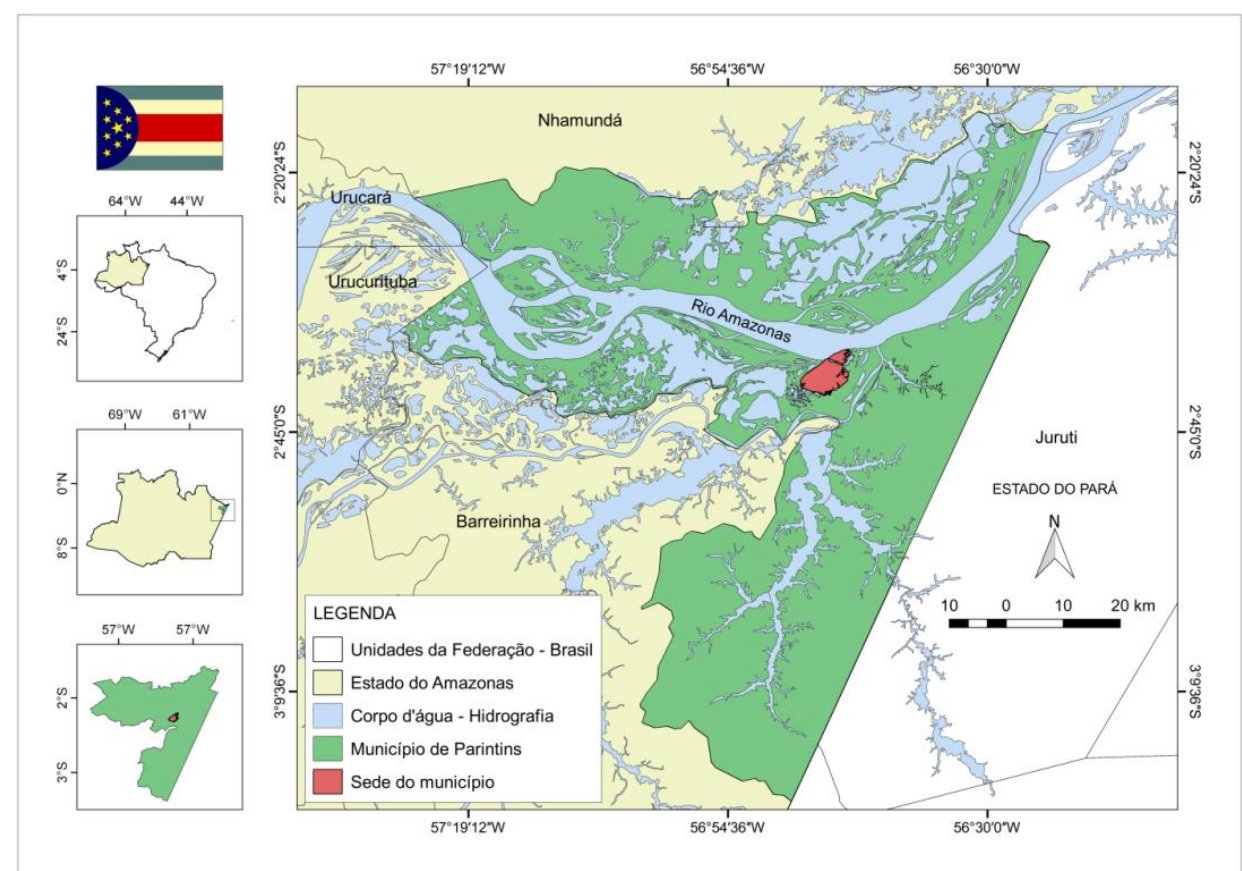

Figura 1: Área de estudo. Fonte: IBGE (2010). Org. MARQUES (2017).

O fenômeno "terras caídas" ocorre principalmente na unidade geoambiental denominada "Planícies Aluvionares Recentes", cujo substrato é formado por sedimentos síltico-arenosos friáveis, inconsolidados, facilmente desagregáveis. Porém, nos últimos anos, no estado do Amazonas, são registrados vários exemplos de municípios que vêm sofrendo com problemas decorrentes do avanço da erosão lateral ao longo de áreas urbanas, ocasionando o comprometimento de suas respectivas "orlas" (CPRM, 2010). 
PROCESSOS FLUVIAIS NO RIO AMAZONAS: EROSÃO LATERAL E IMPLICAÇÕES PARA A CIDADE DE PARINTINS

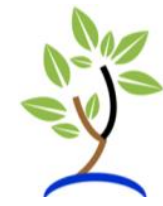

De acordo com o levantamento feito em 2011 pela Companhia de Pesquisas e Recursos Minerais - CPRM, ao longo do rio Amazonas e seus principais afluentes, a cidade de Parintins e mais dezessete sedes de municípios do Estado do Amazonas, encontram-se em constante ameaça pelos ajustes do canal promovidos pela erosão lateral dos taludes marginais, dentre estas, Parintins foi classificada como em situação de alto risco.

Dessa maneira, o presente artigo tem como objetivo principal compreender o processo de erosão lateral do rio Amazonas em frente à cidade de Parintins e as implicações sociais desse fenômeno.

\section{PROCEDIMENTOS METODOLÓGICOS}

Os procedimentos técnico-metodológicos da pesquisa consistiram em medições batimétricas transversais do rio Amazonas; análise de dados hidrológicos; análise granulométrica; tradagem, análise de dados pluviométricos e de velocidade do vento e entrevistas com moradores e instituições públicas.

\section{Medições batimétricas transversais do rio Amazonas}

Os perfis transversais do leito do rio Amazonas foram elaborados a partir dos dados de um ecobatímetro digital da marca GPS/sonar Garmin Echomap 52dv. Para a realização da metodologia foi utilizada uma embarcação de pequeno porte, onde em sua lateral foi instalada uma peça de madeira na posição vertical para que o sensor do aparelho fosse submerso a uma profundidade de aproximadamente $40 \mathrm{~cm}$. A velocidade de deslocamento da embarcação de uma margem à outra durante os trabalhos de campo era de aproximadamente 5 a $6 \mathrm{Km} / \mathrm{h}$ e a cada 10 segundos se registrava em uma caderneta de campo um dado do visor do aparelho correspondente à profundidade do rio.

Durante a batimetria o sensor do aparelho emite um pulso acústico que é refletido pelo leito do rio e captado novamente, fazendo o registro da profundidade. Ao emitir os pulsos de forma contínua, obtém-se o registro linear da geometria do rio a partir do percurso levantado durante a navegação.

Para se compreender a relação entre geometria do canal e erosão lateral, foram realizados quatro perfis batimétricos transversais do rio Amazonas em frente à cidade de Parintins. Os perfis (figura 2) foram elaborados a partir de medições batimétricas de diferentes trechos da frente da cidade para a margem oposta (Ilha do Espírito Santo). As expedições de campo ocorreram no período de vazante dos anos de 2014, 2015 e 2016. 
PROCESSOS FLUVIAIS NO RIO AMAZONAS: EROSÃO LATERAL E IMPLICAÇÕES PARA A CIDADE DE PARINTINS

\section{Dis REVISTA GEONORTE}

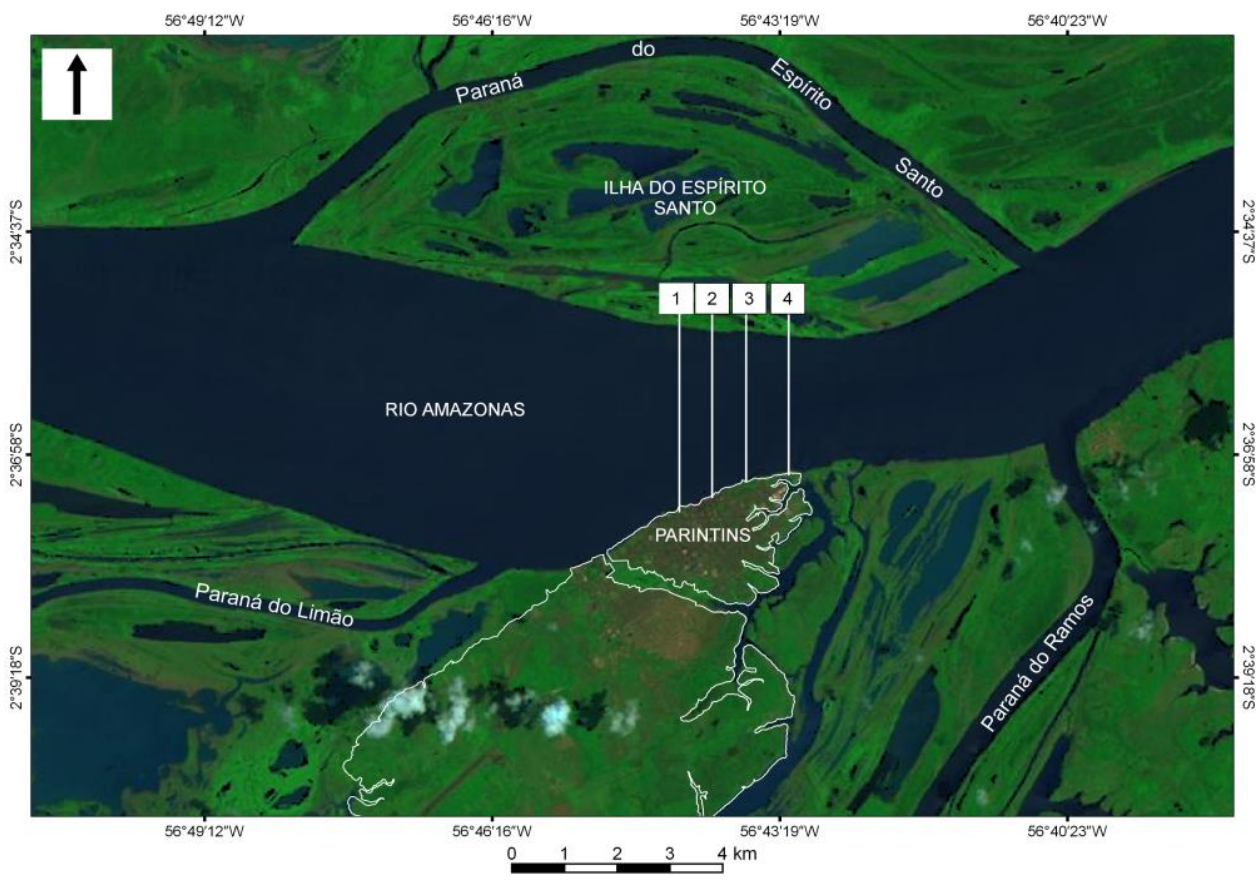

Figura 2. Batimetrias transversais realizadas no rio Amazonas.

Fonte: INPE. Org. MARQUES (2017).

\section{Dados hidrológicos do rio Amazonas}

Os dados referentes à hidrologia do rio Amazonas como vazão, velocidade da corrente e material em suspensão foram obtidos a partir dos relatórios das expedições de campo realizadas pelo Programa HIBAM - Hidrologia e Geoquímica da Bacia Amazônica. Esse programa tem como principal órgão responsável a ANA Agência Nacional de Águas e como instituições participantes a CPRM - Companhia de Pesquisa e Recursos Minerais e o IRD - Institut de Recherche Pour le Développement - Hydrologie - França.

Os dados de vazão levantados pelo referido programa foram obtidos por meio de um correntômetro acústico de efeito Doppler, conhecido como ADCP - Acoustic Doppler Current Profiler. Com esse equipamento é possível fazer medições de vazão em menor tempo e com alta precisão. A vantagem do uso da tecnologia ADCP está na possibilidade de se medir vazões praticamente em qualquer tipo de seção, assim como praticamente em qualquer tipo de regime hidrológico.

Os dados de cota fluviométrica foram obtidos no sistema hidroweb da ANA. A estação de Parintins (código 16350002) possui dados de variação do nível do rio Amazonas entre 1967-2016.

\section{Coleta de material da margem e análise granulométrica}

As amostras de sedimentos foram coletadas em três perfis, sendo o primeiro no limite montante, o segundo no limite médio e o terceiro no setor jusante do terraço fluvial da cidade de Parintins. As amostras foram coletadas a cada metro de profundidade a partir da face exposta da margem. A análise granulométrica foi realizada no Laboratório de Geografia Física da Universidade Federal do Amazonas 
PROCESSOS FLUVIAIS NO RIO AMAZONAS: EROSÃO LATERAL E IMPLICAÇÕES PARA A CIDADE DE PARINTINS

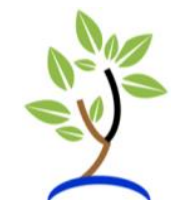

e o método utilizado para o cálculo do teor granulométrico foi o da pipeta, proposto pela EMBRAPA (1997).

Após os cálculos de identificação percentual das frações de areia, silte e argila, foi utilizado o diagrama triangular de Atterberg para a classificação textural do solo. A escolha desse diagrama se deu pelo nível de detalhamento que o mesmo possui em relação aos demais.

\section{Tradagens}

Amostras de sedimentos também foram coletadas na barra de sedimentação longitudinal surgida em outubro de 2016 à montante da cidade de Parintins. $O$ trado utilizado na coleta possui compartimentações que variam de 50 centímetros a 1,5 metros de comprimento. A coleta foi feita em topossequência e o objetivo foi identificar a possível presença de material grosseiro como cascalho e seixo.

\section{Dados pluviométricos e de velocidade do vento}

Os dados referentes à pluviometria, velocidade e direção do vento foram obtidos no site do Instituto Nacional de Meteorologia - INMET. A Estação de monitoramento do referido instituto na cidade de Parintins possui o código 82240 e está localizada na latitude 02.38 (S) e longitude $56.44(\mathrm{~W})$.

O procedimento para observação da ação dos ventos na formação de ondas e turbulências no rio baseou-se no uso em campo de uma biruta com anemômetro instalado próximo à margem do rio Amazonas. $O$ equipamento utilizado nesse procedimento é composto por seis unidades: A - biruta; B - suporte de arco da biruta; C - Mastro superior; D - mastro central; E - mastro inferior e; F - anemômetro digital. Cada mastro possui $60 \mathrm{~cm}$ de comprimento e a função desse suporte foi de elevar a altura da biruta para melhor verificação da direção do vento.

\section{Entrevistas com moradores}

Como técnica de levantamento de informações sobre os problemas vividos pelos moradores e a concepção que os mesmos têm sobre dinâmica fluvial, foram aplicadas entrevistas com os moradores das áreas mais atingidas pela erosão na cidade de Parintins. O questionário utilizado na pesquisa foi elaborado com perguntas abertas e fechadas e o critério para responder as questões teve como base a idade e a vivência na localidade. Assim, as informações foram obtidas com os moradores mais antigos. Durante as entrevistas foi utilizado ainda um gravador para o registro dos depoimentos. No total foram aplicados questionários com dez moradores que eram proprietários dos referidos terrenos.

\section{Levantamento de informações em instituições e órgãos públicos}

O levantamento de informações foi realizado ainda em entrevistas informais na Secretaria Municipal de Obras, Defesa Civil do município e Agência Fluvial de Parintins, órgão vinculado à Marinha do Brasil. A obtenção de reportagens e documentos antigos sobre a erosão do rio Amazonas e os problemas que esta tem 
PROCESSOS FLUVIAIS NO RIO AMAZONAS: EROSÃO LATERAL E IMPLICAÇÕES PARA A CIDADE DE PARINTINS

causando à cidade de Parintins, foram realizados mediante pesquisa no acervo da Rádio Alvorada de Parintins.

\section{RESULTADOS E DISCUSSÕES}

\section{A influência do deslocamento das correntes fluviais sobre o relevo submerso do Rio Amazonas}

O perfil batimétrico transversal $n^{\circ} 01$ (figura 3), foi realizado a partir da Praça do Comunas (margem direita: $2^{\circ} 37^{\prime} 30^{\prime \prime} \mathrm{S}$ e $56^{\circ} 44^{\prime} 21^{\prime \prime} \mathrm{W}$ ) para a ilha do Espírito Santo (margem esquerda: $2^{\circ} 35^{\prime} 36^{\prime \prime} S$ e $56^{\circ} 44^{\prime} 21^{\prime \prime} \mathrm{W}$ ). Nesse ponto o rio Amazonas possui cerca de $3.500 \mathrm{~m}$ de largura. A seção transversal mostra o canal com leito assimétrico e com maior profundidade junto à margem direita. Essa irregularidade do leito é resultado da diferença na distribuição de energia dentro do canal, que é maior nas proximidades da margem direita em função da forma sinuosa do rio.

A seção transversal indica, portanto, que a Praça do Comunas e a área do Verçosa estão seriamente ameaçadas pelos ajustes do canal, pois a relação entre forma, direção do fluxo e posição do talvegue ${ }^{1}$, que chega a atingir $85,8 \mathrm{~m}$ a uma distância de $328 \mathrm{~m}$ da margem, promovem condições para a ocorrência de erosão lateral e vertical acelerada nas proximidades dessa área.

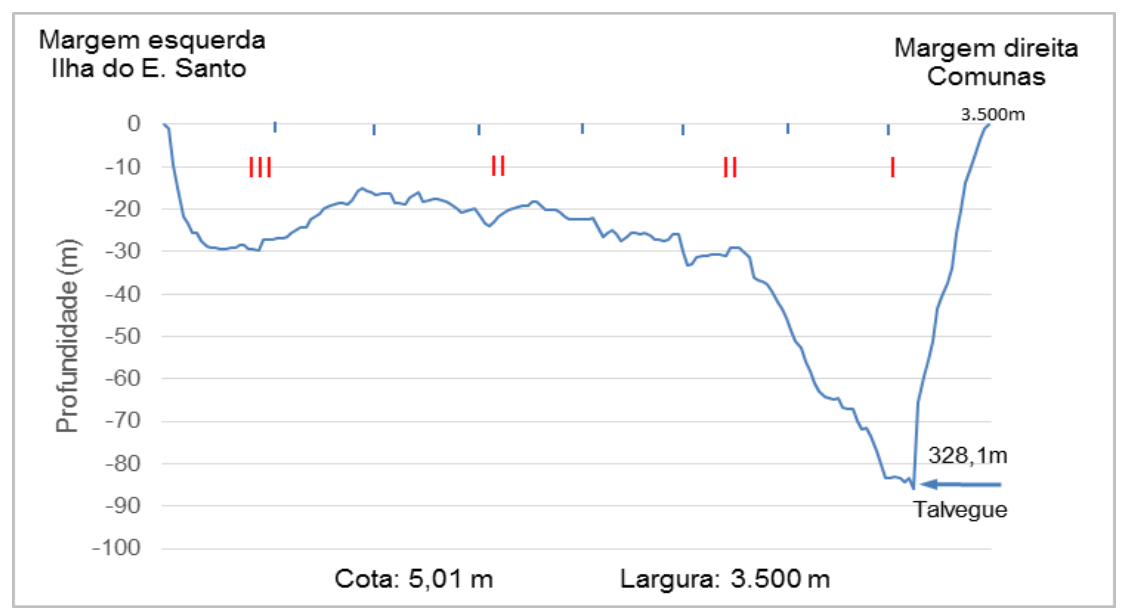

Figura 3. Perfil batimétrico transversal $n^{\circ} 01$. Fonte: MARQUES (2017). Legenda: I - eixo de alta velocidade; II intensa turbulência e velocidade moderada; III - áreas laterais de turbulência e velocidades baixas.

O perfil batimétrico $\mathrm{n}^{\circ} 02$ (figura 4) encontra-se localizado a partir do setor jusante ${ }^{2}$ do Porto da cidade (margem direita: $2^{\circ} 37^{\prime} 23^{\prime \prime} \mathrm{S}$ e $56^{\circ} 44^{\prime} 1^{\prime \prime} \mathrm{W}$ ) e se estende transversalmente até à ilha do Espírito Santo (margem esquerda: $2^{\circ} 35^{\prime} 39^{\prime \prime} \mathrm{S}$ e $56^{\circ}$ 44' 0"W). A largura alcançada pelo rio Amazonas neste ponto é de $3.190 \mathrm{~m}$ e o talvegue também encontra-se encaixado na margem direita.

\footnotetext{
1 Linha de maior profundidade no leito fluvial (GUERRA; GUERRA, 2011).

2 Denomina-se a uma área que fica abaixo de outra, ao se considerar a corrente fluvial pela qual é banhada. É o oposto de montante, que é um lugar situado acima de outro, tomando-se em consideração a corrente fluvial que passa na região. (GUERRA; GUERRA, 2011).
} 
PROCESSOS FLUVIAIS NO RIO AMAZONAS: EROSÃO LATERAL E IMPLICAÇÕES PARA A CIDADE DE PARINTINS

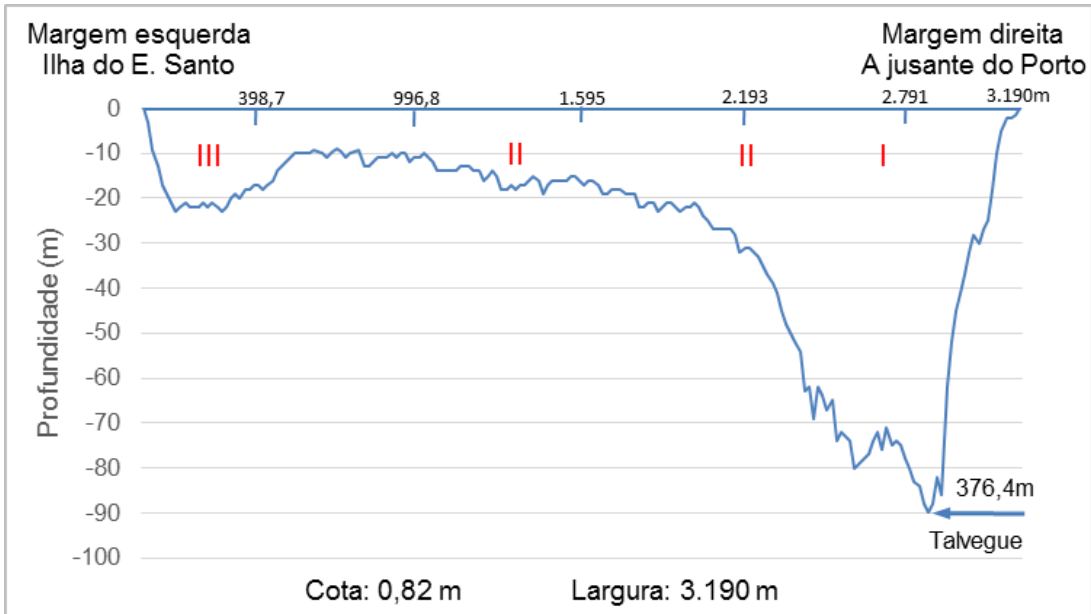

Figura 4. Perfil batimétrico transversal $n^{\circ} 02$. Fonte: MARQUES (2017). Legenda: I - eixo de alta velocidade; II - intensa turbulência e velocidade moderada; III - áreas laterais de turbulência e velocidades baixas.

Embora exista diferença de cotas fluviométricas entre um período e outro de realização das batimetrias, observou-se um ligeiro aumento de energia hidráulica na margem direita em relação ao perfil anterior, pois o talvegue, nesse ponto, apresentou profundidade de até $88 \mathrm{~m}$ a uma distância de $376,4 \mathrm{~m}$ da margem direita. Nota-se ainda que enquanto há aumento de pressão hidráulica próximo à cidade, há diminuição de energia na margem esquerda, pois o canal nesse ponto passa de

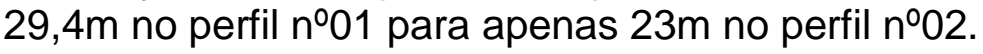

A maior profundidade e irregularidade do canal, no entanto, é observada no perfil batimétrico transversal $n^{\circ} 03$ (figura 5), realizado entre o local conhecido como Caçapava (margem direita: $2^{\circ} 37^{\prime} 17^{\prime \prime} \mathrm{S}$ e $56^{\circ} 43^{\prime} 49^{\prime \prime} \mathrm{W}$ ) e a ilha do Espírito Santo (margem esquerda: $2^{\circ} 35^{\prime} 39^{\prime \prime} S$ e $56^{\circ} 43^{\prime} 49^{\prime \prime} \mathrm{W}$ ). Nesse ponto o canal inicia um estreitamento e atinge $2.980 \mathrm{~m}$, o que possivelmente causa aumento da velocidade da corrente a jusante desse trecho.

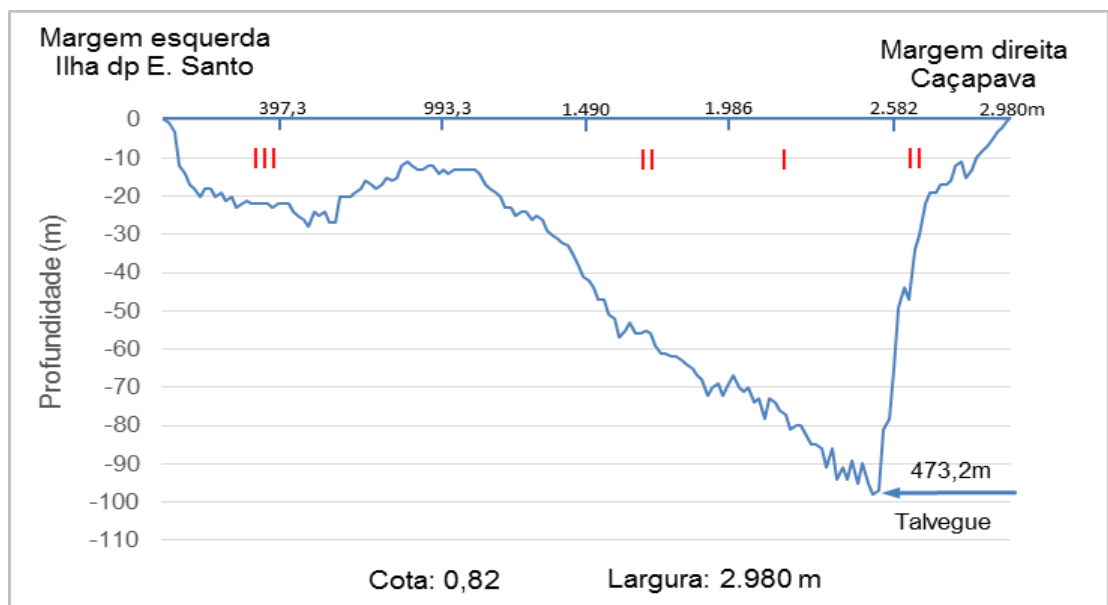

Figura 5. Perfil batimétrico transversal $n^{\circ} 03$. Fonte: MARQUES (2017). Legenda: I - eixo de alta velocidade; II - intensa turbulência e velocidade moderada; III - áreas laterais de turbulência e velocidades baixas. 
PROCESSOS FLUVIAIS NO RIO AMAZONAS: EROSÃO LATERAL E IMPLICAÇÕES PARA A CIDADE DE PARINTINS

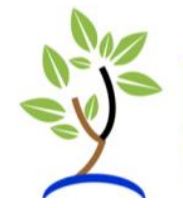

O perfil do leito do canal permite observar que nesse ponto o talvegue do rio Amazonas torna-se largo e profundo, chegando a atingir $98 \mathrm{~m}$ a uma distância de $473,2 m$ da margem direita. Próximo à margem esquerda, a seção transversal aponta a existência de um canal mais raso com regularidade de $20 \mathrm{~m}$.

Enquanto o rio descreve maior pressão rente à margem direita, observa-se do meio do canal até próximo à margem esquerda, um depósito sedimentar com aspecto morfológico assimétrico. Os dados de campo confirmam que nesse ponto durante o período de vazante, surgia há algumas décadas, a antiga "praia do meio", depósito que se expandia longitudinalmente até jusante da cidade de Parintins.

Registros históricos mostram que essa praia foi sendo erodida gradativamente pela ação das correntes do rio Amazonas. Os relatos de moradores mais antigos da cidade de Parintins descrevem que o local era muito visitado por banhistas para práticas de lazer e que o mesmo teria surgido pela última vez no final da década de 1980.

No limite leste da cidade, o levantamento batimétrico realizado entre o trecho final da Rua Portugal (margem direita: $2^{\circ} 37^{\prime} 9^{\prime \prime} S$ e $56^{\circ} 43^{\prime} 14^{\prime \prime} \mathrm{W}$ ) e a ilha do Espírito Santo (margem esquerda: $2^{\circ} 35^{\prime} 43^{\prime \prime} S$ e $56^{\circ} 43^{\prime} 12^{\prime \prime} \mathrm{W}$ ) mostra que para jusante, o canal fica mais estreito e a área ocupada pelo talvegue torna-se mais extensa, aumentando consequentemente, áreas de maior velocidade e turbulência (figura 6).

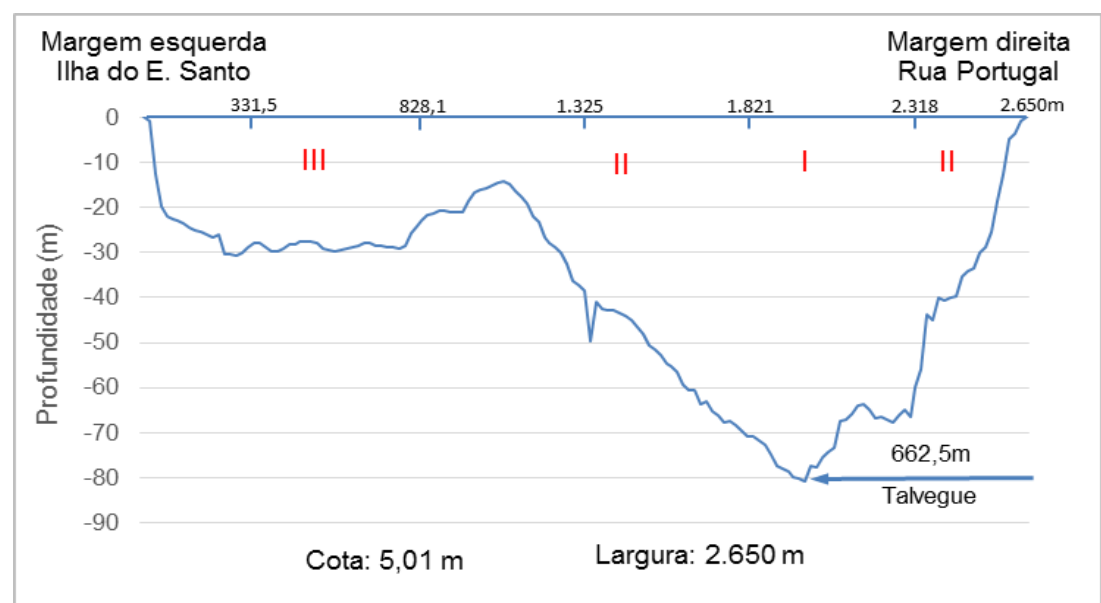

Figura 6. Perfil batimétrico transversal $n^{\circ} 04$. Fonte: MARQUES (2017). Legenda: I - eixo de máxima velocidade; II intensa turbulência e velocidade moderada; III - áreas laterais de turbulência e velocidades baixas.

Em cada um dos perfis é possível notar que cada zona de máxima velocidade do rio é acompanhada por duas zonas de máxima turbulência. Assim, observou-se que a zona I, descrita nas legendas dos perfis batimétricos, é caracterizada por correntes onde a velocidade e vazão é mais acentuada, as quais transportam quaisquer sedimentos em suspensão difundidos em seu interior. Na zona II observou-se intensa turbulência e velocidade moderada. E na zona III considera-se o local para onde a turbulência pode migrar, ocasionando a deposição dos sedimentos em suspensão difundido na zona II. 
PROCESSOS FLUVIAIS NO RIO AMAZONAS: EROSÃO LATERAL E IMPLICAÇÕES PARA A CIDADE DE PARINTINS

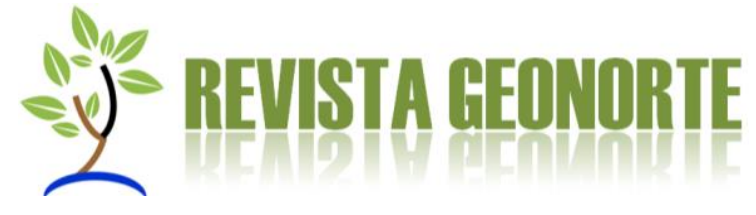

Para fins de análise comparativa entre as características da geometria das formas de fundo do rio Amazonas em frente à cidade de Parintins, a tabela 1 mostra uma síntese dos principais dados obtidos.

Tabela 1. Dados de medições do rio amazonas em frente à cidade de Parintins.

\begin{tabular}{ccc}
\hline PERFIS & LARGURA DO CANAL & PROFUNDIDADE DO TALVEGUE \\
TRANSVERSAIS & $3.500 \mathrm{~m}$ & $85,8 \mathrm{~m}$ \\
\hline PERFIL № 01 & $3.190 \mathrm{~m}$ & $90 \mathrm{~m}$ \\
PERFIL № 02 & $2.980 \mathrm{~m}$ & $98 \mathrm{~m}$ \\
PERFIL № 03 & $2.650 \mathrm{~m}$ & $80,8 \mathrm{~m}$ \\
PERFIL № 04 & &
\end{tabular}

Fonte: MARQUES (2017).

Os perfis transversais do rio Amazonas mostraram que a corrente principal deslocase em direção ao terraço onde está a cidade, pois a forma sinuosa da margem e o estreitamento do canal que varia de $3.500 \mathrm{~m}$ de largura no limite superior (montante) para apenas $2.650 \mathrm{~m}$ no limite inferior (jusante), contribui para que ocorra pressão comprimida do volume de água no trecho mais jusante da cidade, que corresponde ao bairro Santa Clara, tornando esse setor mais suscetível a sofrer erosão.

\section{A pressão e as forças hidráulicas atuantes no canal}

Vários fatores hidráulicos afetam a estabilidade das margens, no entanto, a sua maioria depende das propriedades específicas da água que se relacionam com as forças hidráulicas atuantes dentro do canal.

Carvalho (2006) considera que no rio Amazonas os principais fatores que atuam dentro do canal e que se aponta como os principais responsáveis pela erosão lateral é a grande energia contida em seu descomunal volume de água, associado às "macroturbulências" com que os fluxos se deslocam dentro do canal e o peso que esse volume de água exerce dentro do mesmo.

Os dados de medições hidrológicas realizadas logo a jusante da cidade de Parintins pelo Programa HIBAM, mostram que em 12 de dezembro de 2003, quando o rio Amazonas estava em período de vazante, a vazão média foi de $107.393 \mathrm{~m}^{3} / \mathrm{s}$. Em abril de 2005, quando o rio estava enchendo, a expedição encontrou uma vazão média de $182.180 \mathrm{~m}^{3} / \mathrm{s}$. E em junho do mesmo ano, quando o rio atinge a cota máxima de cheia, a vazão média foi de $192.262 \mathrm{~m}^{3} / \mathrm{s}$. Ou seja, o volume de água que passa na frente da cidade varia de 107.000 a $190.000 \mathrm{~m}^{3} / \mathrm{s}$. É sem dúvida, o ataque desse descomunal volume de água, associado com a forma turbulenta com que se desloca dentro do canal e atinge a margem que sem dúvida atua como o principal responsável pela erosão vertical e lateral, comprometendo a frente da cidade.

Em função da baixa declividade em seu perfil longitudinal, a velocidade do fluxo do rio Amazonas, ao contrário da vazão, possui pouco poder abrasivo. A velocidade média alcançada em frente à cidade durante as expedições realizadas pelo programa HIBAM em junho de 2005 , foi de $1.466 \mathrm{~m} / \mathrm{s}$, o equivalente a $5.27 \mathrm{~km} / \mathrm{h}$. Esse dado, mesmo quando relacionado ao valor médio de $81,7 \mathrm{mg} / \mathrm{l}$ de material transportado em suspensão, atua apenas na remoção de pequenas partículas do material da margem. 
PROCESSOS FLUVIAIS NO RIO AMAZONAS: EROSÃO LATERAL E IMPLICAÇÕES PARA A CIDADE DE PARINTINS

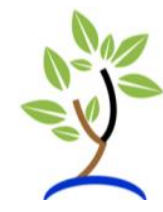

O perfil da magnitude da velocidade do rio Amazonas em frente à cidade mostra que as maiores velocidades atuantes no período da enchente ocorrem no meio do canal e se estendem até próximo à margem direita onde o talvegue está sendo encaixado (figura 7). Observou-se ainda que no período de vazante a magnitude da velocidade diminui consideravelmente (figura 8).

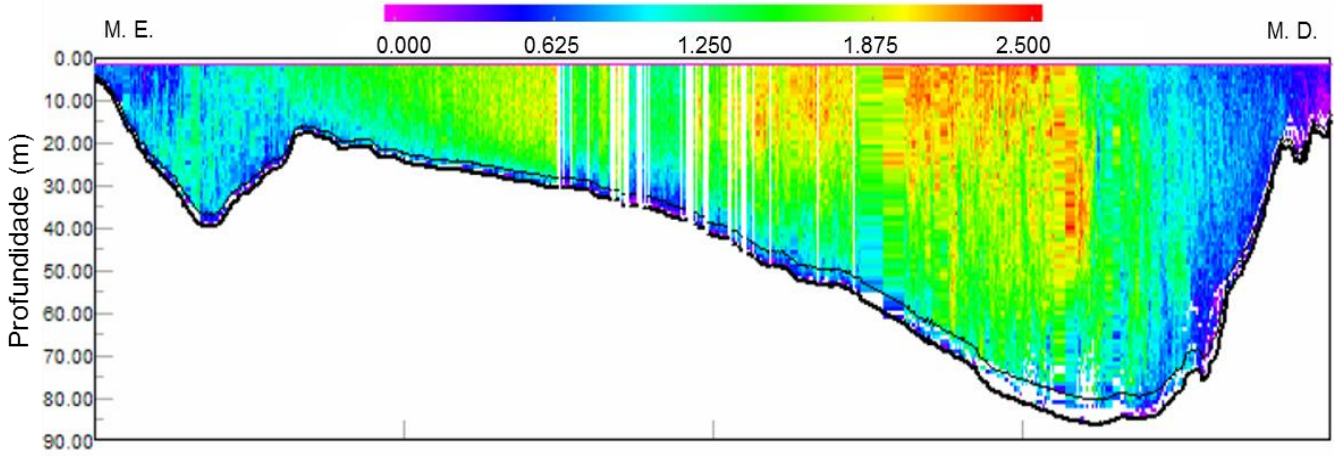

Figura 7. Perfil da velocidade do rio Amazonas durante a enchente $(\mathrm{m} / \mathrm{s})$. Fonte: HIBAM. As maiores velocidades correspondem às cores quentes (amarelo ao vermelho) e os menores valores às cores frias (azul escuro ao azul claro). Data: 22/03/2005.

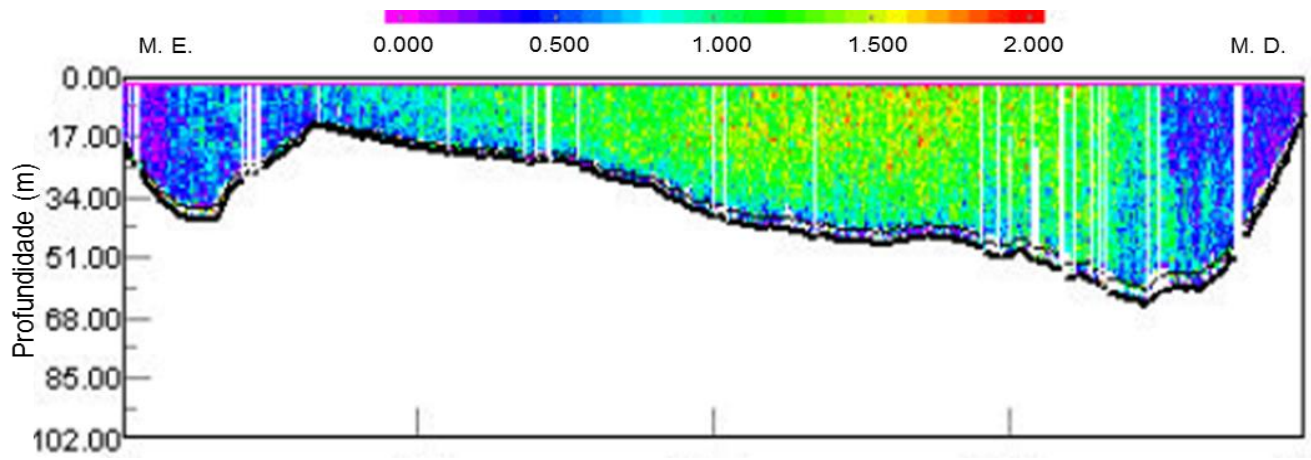

Figura 8. Perfil da velocidade do rio Amazonas durante a vazante $(\mathrm{m} / \mathrm{s})$.

Fonte: HIBAM. As maiores velocidades correspondem às cores quentes (amarelo ao vermelho) e os menores valores às cores frias (azul escuro ao azul claro). Data: 12/12/2003.

A localização da cidade em um ponto de inflexão do canal (margem côncava) favorece que a corrente seja deslocada em direção à cidade por meio do fluxo helicoidal (figura 9). Suguio e Bigarella (1990) apontam que esse movimento atua de forma tridimensional e ataca mais as margens côncavas aumentando a sinuosidade das curvas. 

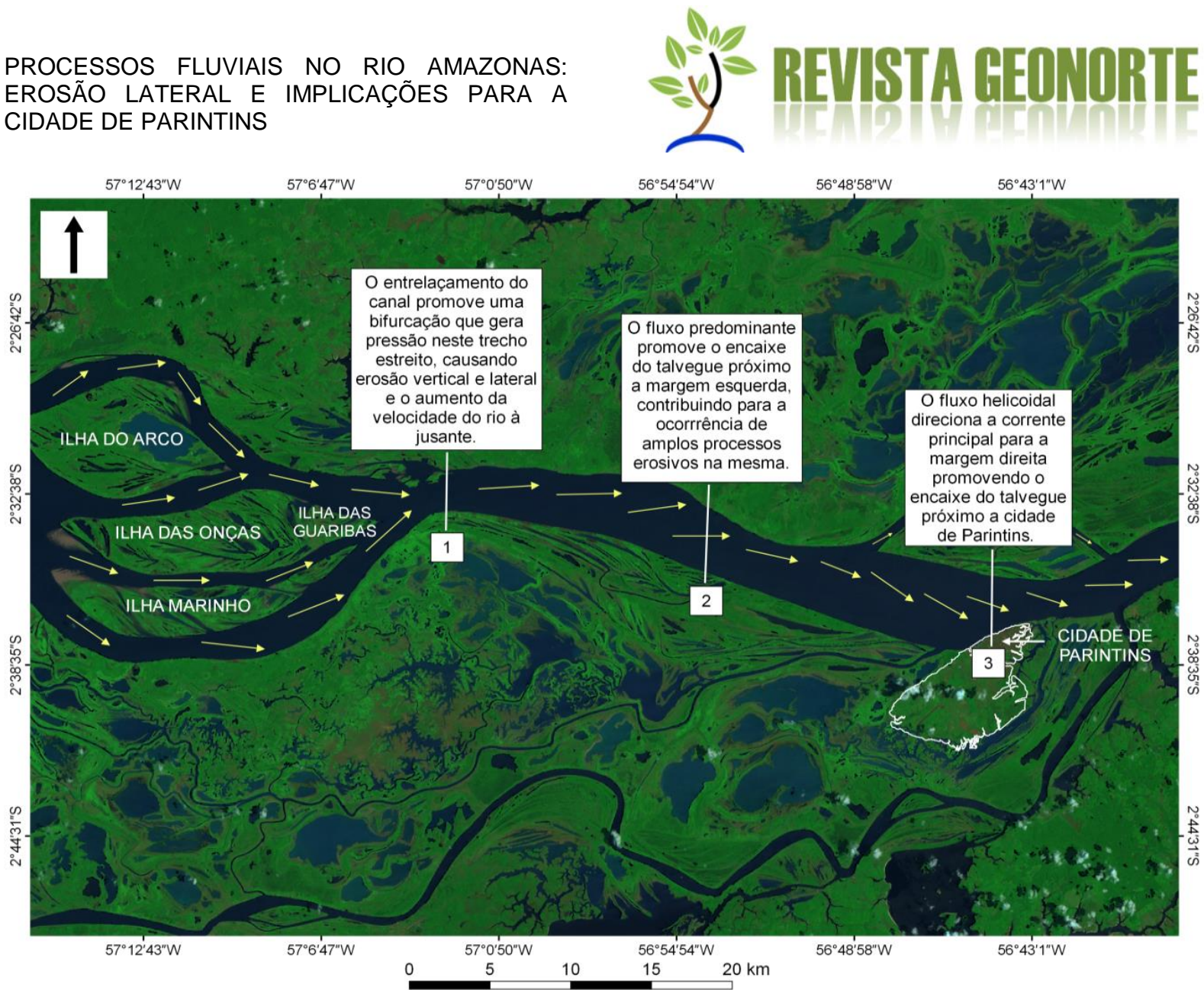

Figura 9. Padrões de fluxo e sua relação com a forma e geometria do canal. Fonte: INPE. Org. MARQUES (2017).

O fluxo helicoidal sempre é acompanhado da superelevação do nível da água junto à margem côncava em consequência do desvio do eixo de máxima velocidade do centro do canal (figura 10).

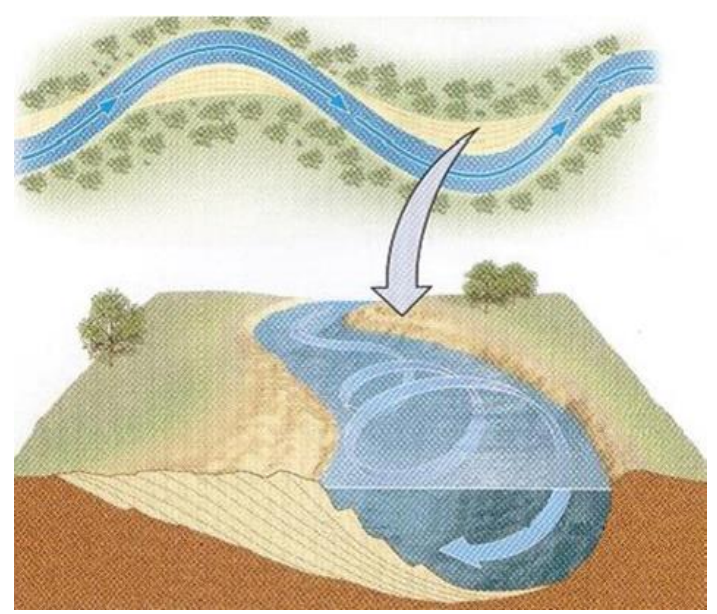

Figura 10. Fluxo helicoidal em margem côncava. Fonte: PRESS et al. (2006).

Próximo à superfície, o máximo da intensidade do fluxo helicoidal orienta-se no sentido da margem côncava, ocorrendo o inverso em profundidade junto ao leito do canal. Na curva seguinte o eixo de máxima velocidade desvia-se no sentido inverso, completando assim, a ação do movimento. A aceleração radial do fluxo dá origem ao 
PROCESSOS FLUVIAIS NO RIO AMAZONAS: EROSÃO LATERAL E IMPLICAÇÕES PARA A CIDADE DE PARINTINS

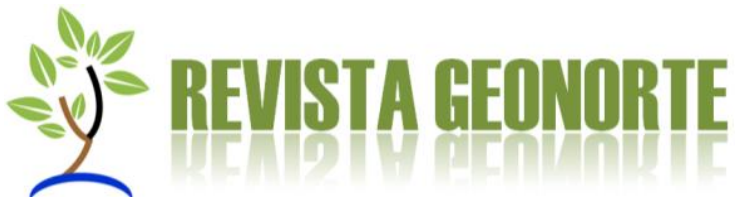

excesso de pressão sobre o banco côncavo, onde se processa a erosão, e um déficit de pressão do lado oposto onde ocorre sedimentação.

\section{Os componentes do solo da margem}

A análise granulométrica mostrou que existe uma diferença na composição do material que varia de montante para jusante em frente à cidade. Os dados indicam que no perfil $\mathrm{n}^{\circ} 01$, localizado no limite superior montante, o material é mais arenoso, no entanto, a presença de rochas lateríticas próximas à base e a vegetação, contribuem para a estabilidade da área (figura 11).

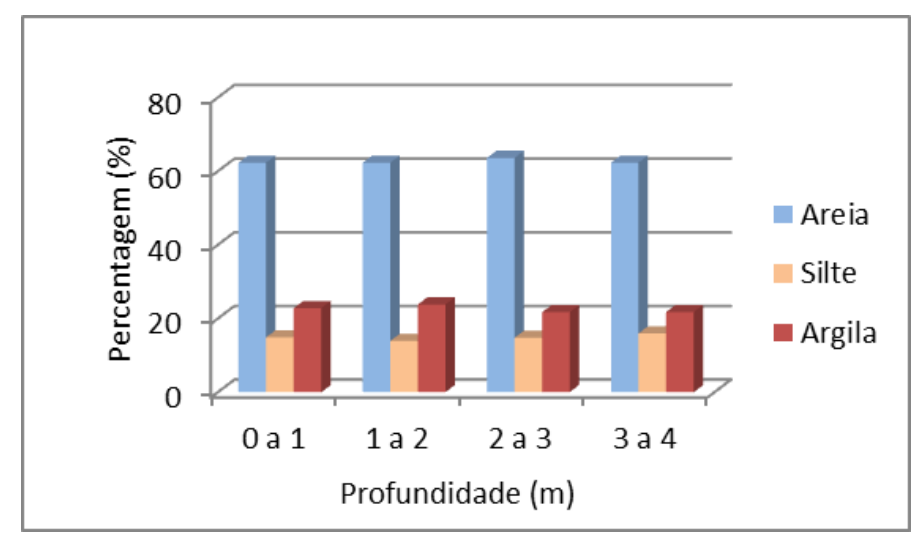

Figura 11. Perfil $n^{\circ} 01$. Fonte: MARQUES (2017).

Mais à jusante do canal, no perfil $n^{\circ} 02$, não tendo estrato laterítico na base $\mathrm{e}$ apresentando frações de areia superiores as de silte e argila (figura 12), a erosão é mais acelerada.

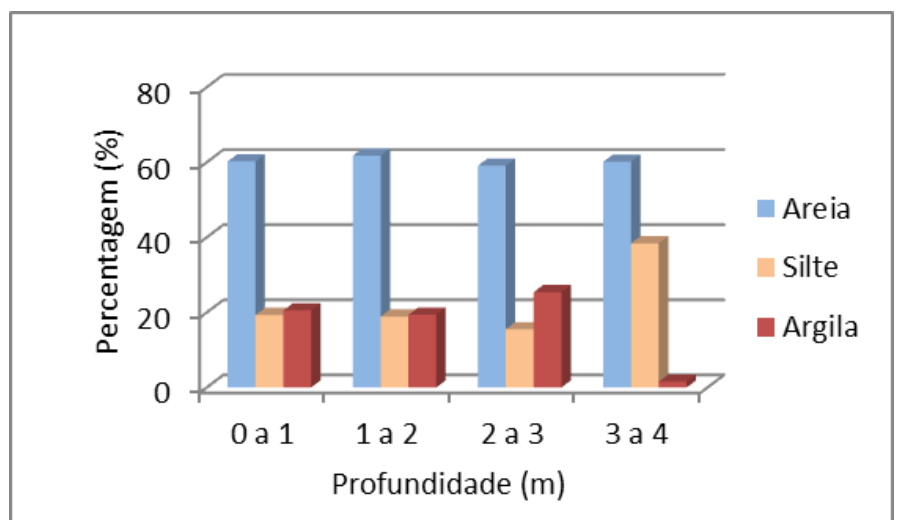

Figura 12. Perfil $n^{\circ} 02$. Fonte: MARQUES (2017).

O perfil $n^{\circ}$ 03, localizado no trecho mais jusante da cidade, mostra uma elevada concentração de argila (figura 13). As propriedades desse material fazem com que a erosão seja mais acentuada nesse setor, pois a perda de umidade no interior do pacote sedimentar condiciona a ocorrência de fissuras verticais que promovem 0 desmoronamento da parte superior e média da margem. 
PROCESSOS FLUVIAIS NO RIO AMAZONAS: EROSÃO LATERAL E IMPLICAÇÕES PARA A CIDADE DE PARINTINS

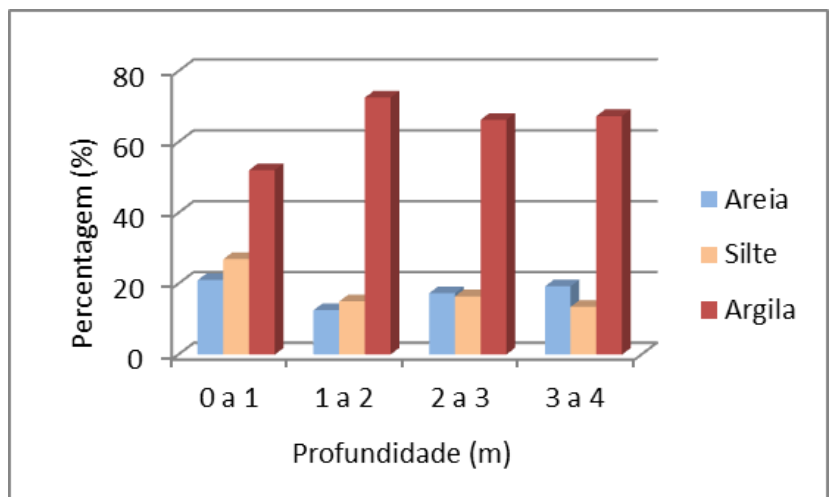

Figura 13. Perfil $n^{\circ}$ 03. Fonte: MARQUES (2017).

\section{As condições climáticas e seus efeitos sobre as margens}

A atuação dos fatores climáticos na desagregação do material das margens é amplamente observada e considerada no conjunto de mecanismos que envolvem a migração dos canais. No rio Amazonas, Carvalho (2006) e Meis (1968) apontam que as chuvas e, sobretudo, os ventos com direção predominante ao sentido oposto da corrente do rio, estão entre os fatores que contribuem mais diretamente com esse processo.

Na região Amazônica, Tricart (1977) observou que a grande concentração de chuvas em determinados meses provoca infiltração do pacote sedimentar e consequente desmonte do material das margens por excesso de peso e desagregação do material saturado. Embora se verifique com mais intensidade sobre formações holocênicas (várzea) em função das propriedades do material, a concentração de fortes chuvas também atua de forma significativa em terrenos mais antigos, inclusive em área urbana.

A estação meteorológica do INMET, localizada na cidade de Parintins, mostra que o período chuvoso começa a se intensificar a partir dos meses de novembro/dezembro e se estende até final de março/abril. Observa-se que nos primeiros quatro meses do ano o índice médio é superior a $300 \mathrm{~mm}$ e chega a mais de $380 \mathrm{~mm}$ no mês de março, quando se verifica a maior potência pluviométrica nessa estação.

Apesar da concentração de chuvas no local não ser responsável pela subida do nível do rio Amazonas, e sim as precipitações que ocorrem no curso superior dos seus afluentes, o período de maior índice pluviométrico registrado em Parintins coincide com a subida de nível do rio Amazonas e assim, associa-se o efeito erosivo causado pelas chuvas ao aumento da velocidade do fluxo e o consequente aumento da pressão do volume de água sobre as margens.

Os dados do INMET mostram que no ano de 2013, quando se registrou a maior média pluviométrica dos últimos 15 anos na estação de Parintins, as maiores médias ocorreram em janeiro, quando atingiu $709,2 \mathrm{~mm}$ precipitados durante 25 dias desse mês, e em março, quando a média alcançou $666,9 \mathrm{~mm}$, sendo que só no dia 24 choveu 128,9 mm. Essa concentração de chuva tem a capacidade de acelerar o processo erosivo sobre as margens por meio da infiltração no pacote sedimentar, como também contribui com o processo de erosão superficial sobre as mesmas. 
PROCESSOS FLUVIAIS NO RIO AMAZONAS: EROSÃO LATERAL E IMPLICAÇÕES PARA A CIDADE DE PARINTINS

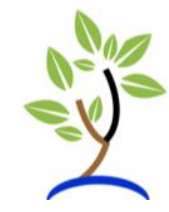

Com relação à ação dos ventos, Fontes (2002, p. 199) considerou que este fator atua de forma indireta, pois "eles são em parte responsáveis pela formação das ondas e estas, sim, atuam diretamente na remoção de partículas das margens".

O vento exerce uma força de arraste sobre a superfície do espelho d'água e esta força é responsável pela geração das ondas. Simons (1982, apud Fontes, 2002) aponta que a magnitude e frequência destas ondas superficiais geradas pelo vento são dependentes de variáveis como velocidade, duração, distância atingida em função da sua direção, orientação, dimensões da superfície de água exposta a ação do vento, profundidade e outras variáveis menores.

As condições relacionadas à velocidade e direção predominante do vento que adentram em sentido oposto ao fluxo (ventos de nordeste), bem como as características do rio Amazonas em frente à cidade de Parintins, que possui uma calha larga e pouco sinuosa, variável entre $3.500 \mathrm{~m}$ de largura no limite montante e $2.650 \mathrm{~m}$ no limite jusante, e com profundidade máxima que chega a uma média de $87 \mathrm{~m}$, apresenta condições favoráveis à ação dos ventos e a formação de corredores de vento que atuam na formação de ondas.

De acordo com os dados disponíveis pelo INMET, as maiores incidências de tempestades acompanhadas de rajadas de vento acontecem no meio do ano com máximas que variam entre 51 a $60 \mathrm{~km} / \mathrm{h}$. O uso de biruta e anemômetro em campo mostrou que rajadas com essa intensidade são capazes de formar sequências de ondas e turbulências no rio Amazonas, colocando em risco a navegação.

Os dados permitem observar que a frequência de rajadas acima $50 \mathrm{~km} / \mathrm{h}$ ocorre entre os meses de maio e agosto. Isto mostra que a formação de corredores de vento com maior intensidade coincide com o período em que rio atinge seu pico de enchente e se estende até o momento em que o mesmo passa descer com maior velocidade.

\section{A ação humana na aceleração do processo}

Dentre as ações humanas que potencializam a erosão lateral na cidade de Parintins, considera-se que a sinuosidade da margem pode estar sendo forçada pela construção e elevação de duas ruas sobre um canal que antes fluía por entre a cidade e que no período de enchente se ligava ao rio Amazonas.

A elevação do nível da Rua Paraíba no bairro Itaúna I, e principalmente a construção do trecho da Rodovia Odovaldo Novo, no bairro São José, possivelmente tiveram implicações na direção do fluxo do rio Amazonas nas proximidades da cidade.

Estas vias que foram construídas transversalmente sobre a extensão do referido canal, podem estar contribuindo para a intensificação do processo de erosão em frente à cidade, pois durante o período de cheia, o mesmo poderia amenizar a pressão hidráulica do rio Amazonas, no entanto, ao se colocar o aterro, criou-se condições para o aumento da pressão hidráulica a jusante e que pode tornar a margem ainda mais sinuosa.

Outro fator que possui relação foi a retirada de rochas do extrato laterítico da base da margem na frente da cidade. Essa formação laterítica consiste em uma proteção natural, no entanto, em alguns locais como na Rua Armando Prado, próximo a 
PROCESSOS FLUVIAIS NO RIO AMAZONAS: EROSÃO LATERAL E IMPLICAÇÕES PARA A CIDADE DE PARINTINS

Colônia dos Pescadores, essas rochas foram sendo retiradas por administrações públicas passadas e também por moradores para a construção de residências.

A canalização da rede do esgoto doméstico e pluvial da cidade também contribui para o processo de erosão da margem. O sistema de esgoto da cidade no início da década de 1980 atingia aproximadamente 10 ou $20 \%$ das áreas que necessitavam desse serviço. Parte desse sistema foi construído na década de 1960 e em alguns locais o mesmo já precisava de reparos. Segundo o livro de Atas Câmara Municipal de Parintins, a partir da década de 1980 esse sistema começou a ser ampliado para toda cidade, no entanto, nas "ruas da frente" a rede de esgoto foi em sua maior parte direcionada para o rio Amazonas e a mesma passou a escoar as águas pluviais e das residências sobre a zona de erosão do rio.

Atualmente o escoamento superficial da água esgoto, bem como sua infiltração, também tem contribuído para o comprometimento de alguns trechos da estrutura do muro de arrimo, como é o caso da Praça do Comunas, no centro da cidade (figura 14).

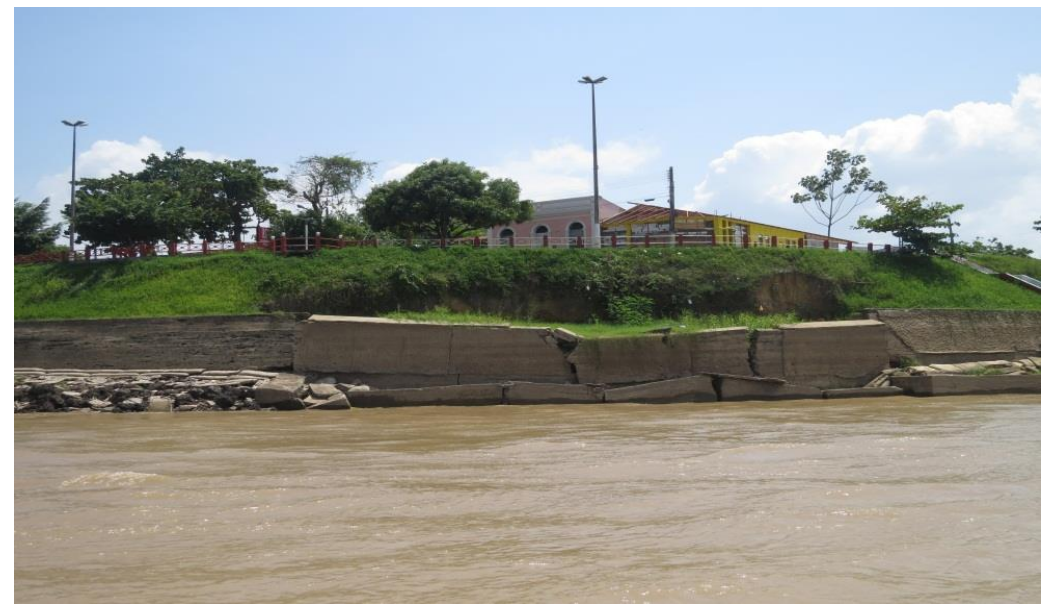

Figura 14. Situação do muro de contenção na Praça do Comunas.

Foto: SOUZA (2014).

Outro fator de ordem antrópica que acelera o processo é a formação de ondas geradas pelo deslocamento de barcos regionais, lanchas expressos e navios pelo rio Amazonas. O efeito desse processo na desagregação das margens do rio Amazonas foi observado nas obras de Carvalho (2006; 2012). No entanto, Christofoletti (1981), chama atenção para o fato que o registro da sua ação erosiva nas margens dos rios nem sempre são conservados.

\footnotetext{
Nos trechos aluviais, todavia, as marcas e as formas topográficas erosivas são facilmente obliteradas pela sedimentação posterior ou pela intensa movimentação detrítica [...]. Ao contrário, as marcas erosivas e as formas topográficas em leitos rochosos são mais perenes, facilmente percebidas e criam a imagem falsa de que a erosão só é atuante nesses trechos (CHRISTOFOLETTI, 1981, p. 235 a 326).
}

O registro erosivo dos banzeiros sobre as margens, embora difícil de reconhecer e quantificar, não pode ser desconsiderado enquanto agente que atua de forma direta na erosão lateral, pois, mesmo possuindo pouco poder abrasivo quando deslocado em baixa intensidade, sua ação acontece a quase todo momento devido ao contínuo fluxo de embarcações pelo rio Amazonas. 
PROCESSOS FLUVIAIS NO RIO AMAZONAS: EROSÃO LATERAL E IMPLICAÇÕES PARA A CIDADE DE PARINTINS

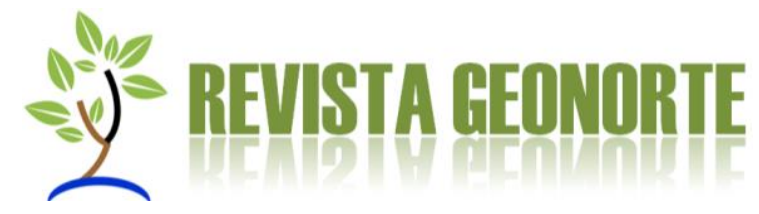

Além dos barcos regionais, os navios também têm contribuído com o processo. Segundo Carvalho (2006 p. 84) "o aumento no trânsito dessas grandes embarcações de carga foi intensificado no rio Amazonas a partir da década de 1970, em função do desenvolvimento da Zona Franca de Manaus". Como Parintins encontra-se no rio Amazonas a jusante de Manaus, as grandes embarcações de carga vindas a partir do Atlântico para a capital do Estado, precisam passar em frente à cidade, e embora, na maioria das vezes reduzam sua velocidade, a onda formada ainda chega a deslocar um grande volume de água contra as margens.

\section{Deposição e as possíveis mudanças no padrão de fluxo do Rio Amazonas}

Amazonas, ao ser considerado um rio jovem do ponto de vista do processo evolutivo da terra, ainda está por encontrar seu leito definitivo. Essa condição faz com que ocorra um contínuo ajuste de variáveis como forma, seção transversal, padrões de fluxo e mudanças no transporte de carga de sedimentos que são, em grande parte, controlados pela intensa dinâmica fluvial dos mecanismos que envolvem os processos de erosão, transporte e deposição.

Essa característica acaba por promover mudanças significativas na paisagem ribeirinha que se verificam não somente por erosão das margens, mas também por diversas formas aluviais que surgem do acúmulo de partículas transportadas e depositadas em determinados trechos do rio, e que ao se estabilizarem, podem gerar mudanças de comportamento dos padrões de fluxo do canal.

Como resultado dessa dinâmica e tendo como principais influências as condições pouco turbulentas das correntes e a elevada carga de sedimentos transportadas no fundo e em suspensão, formou-se uma barra sedimentar acrescida longitudinalmente em mais de $700 \mathrm{~m}$ de extensão à aproximadamente $7 \mathrm{~km}$ a montante da sede do município de Parintins.

Essa formação aluvial passou a ser conhecida como "praia do meio" em referência ao antigo depósito que surgia há algumas décadas em frente à cidade, no entanto, trata-se de uma formação mais recente que, ao contrário do antigo depósito, situa-se próximo da margem direita, a montante da foz do paraná do Limão.

Os registros da régua fluviométrica da Marinha do Brasil localizada na cidade de Parintins, mostram que o nível do rio Amazonas em 27 de outubro de 2016, alguns dias após o surgimento do depósito, encontrava-se em 0,68 metros, e na vazante do ano anterior, na mesma data, o rio estava com o nível de $-0,21$ metros. Isso demonstra que mesmo o rio Amazonas registrando valores de cota inferiores durante a vazante de 2015, não houve o surgimento do depósito.

Considera-se, portanto, que grande parte da carga passou a ser depositada durante a enchente seguinte (figura 15). A diferença de cota do rio entre os dois anos (89 $\mathrm{cm})$ somada à altura do depósito $(24 \mathrm{~cm})$, mostra que o valor mínimo de elevação acrescido verticalmente durante a última enchente foi de $1,13 \mathrm{~m}$ de altura sobre uma área de $92.471 \mathrm{~m}^{2}$ (perímetro emerso). 


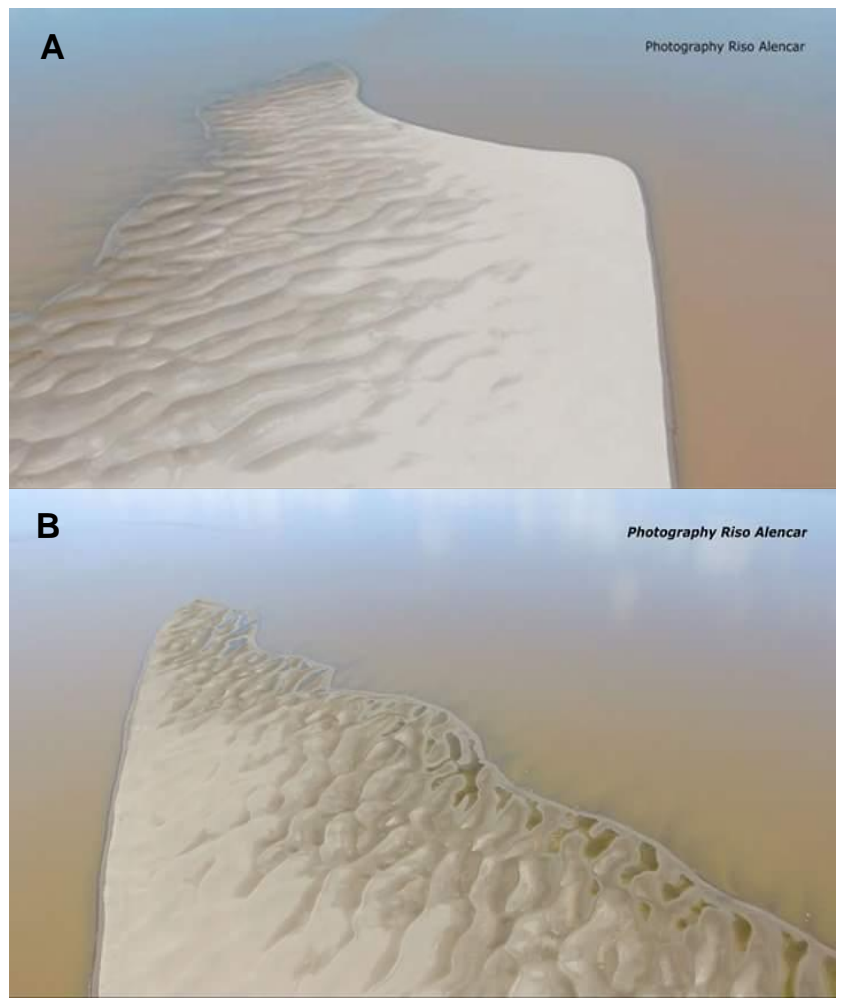

Figura 15. Imagem aérea da barra de sedimentação. Foto: ALENCAR (2016). A - faixa montante do depósito; $B$ - faixa jusante.

A seção transversal realizada a partir do ponto emerso dessa feição para as margens esquerda e direita do rio Amazonas, revela que o talvegue encontra-se mais próximo da margem esquerda, realizando maior pressão nessa faixa e na lateral do depósito que encosta na parede do canal (figura 16). Durante as expedições de campo, verificou-se que a faixa do depósito que se volta para onde está o talvegue constitui uma superfície bastante íngreme em função da maior distribuição de energia nesse setor do canal.

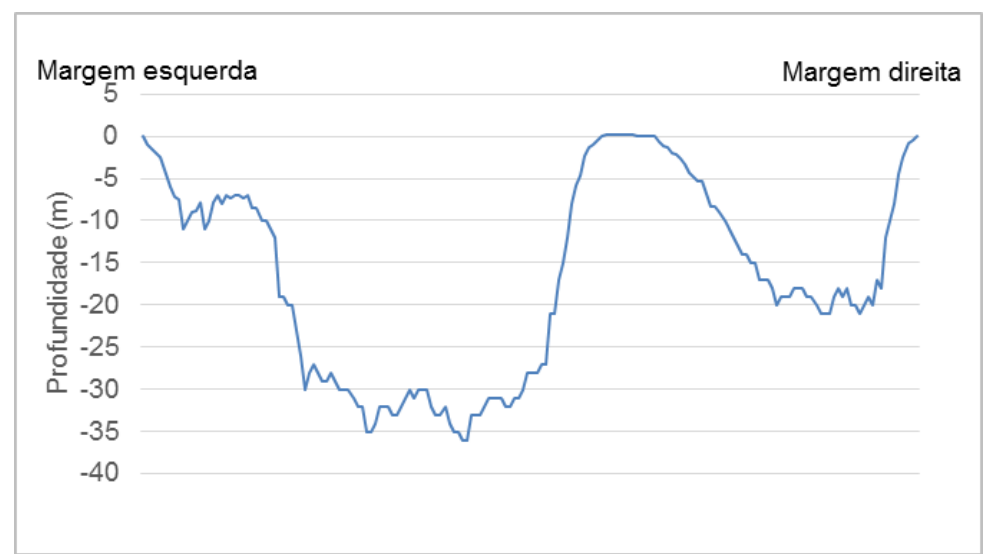

Figura 16. Perfil transversal da barra de sedimentação.

Fonte: MARQUES (2017).

A faixa do depósito que se estende em direção ao canal que se encontra pela margem direita, apresenta um relevo fluvial mais suave e possui cobertura 
PROCESSOS FLUVIAIS NO RIO AMAZONAS: EROSÃO LATERAL E IMPLICAÇÕES PARA A CIDADE DE PARINTINS

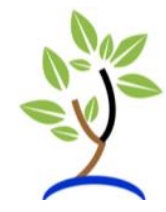

sedimentar em forma de pequenas dunas (micro-ondulações). Em função da ação direta das correntes, a face montante é mais íngreme, enquanto que a faixa jusante se estende rampeada abaixo do nível das águas no sentido longitudinal e até cerca de 400 metros de distância de onde está emerso, o nível do rio não ultrapassou 3,5 metros de profundidade.

A extensão do perímetro do banco em profundidade representa perigo constante à navegação durante a vazante, pois em certos pontos, mesmo a uma distância de cerca de $1 \mathrm{~km}$, o nível do rio não chega ultrapassar 1 metro de profundidade.

Em uma sequência de tradagens realizadas com 1,5 metros de profundidade ao longo do depósito só foi encontrado material fino, o que indica que o mesmo pode ser erodido nos próximos anos. Caso venha se estabilizar e receber um aporte maior de sedimentos, possíveis alterações na hidrodinâmica podem modificar o fluxo principal do canal (figura: 17) e promover mudanças significativas na espacialização dos processos erosivos e deposicionais neste trecho do rio Amazonas.

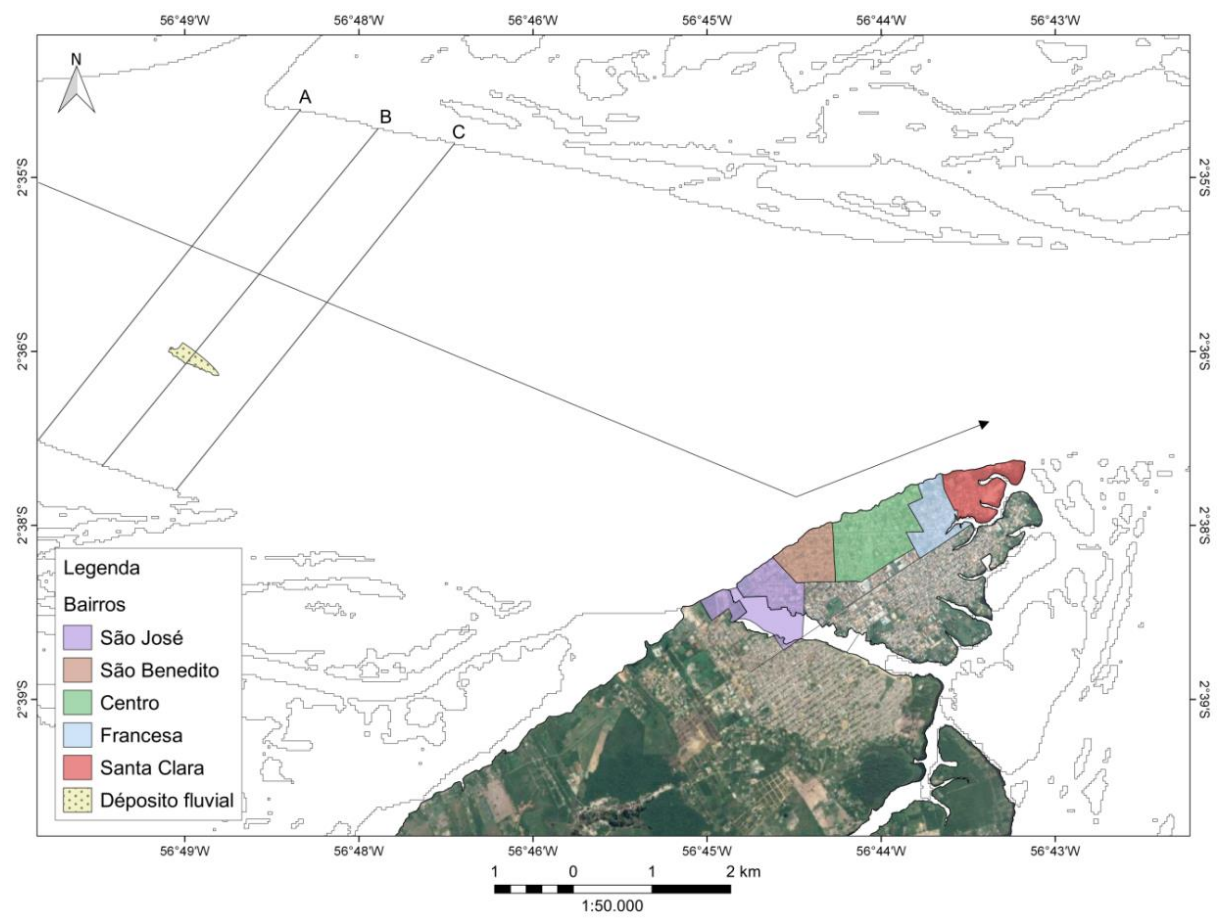

Figura 17. Situação do depósito em relação ao fluxo principal do rio Amazonas. Fonte: U.S. Geological Survey. Org. MARQUES (2017). A, B, C - Localização das batimetrias; Seta - sentido do fluxo principal.

Mesmo que não se tenha pretensão de responder tais questões, considera-se que a possível expansão do depósito, dependendo do sentido espacial do aporte de sedimentos, poderá desviar para o meio do canal o fluxo principal que acompanha a linha do talvegue do rio Amazonas. Caso isso venha acontecer, haverá, à jusante, uma diminuição progressiva da pressão hidráulica que atinge a margem em frente à cidade de Parintins e essa faixa de terraço passaria então a se tornar uma zona com predomínio de deposição do rio. 
PROCESSOS FLUVIAIS NO RIO AMAZONAS: EROSÃO LATERAL E IMPLICAÇÕES PARA A CIDADE DE PARINTINS

\section{Implicações da dinâmica fluvial para a cidade de Parintins}

\section{Comprometimento do muro de arrimo}

Os primeiros registros que se tem da criação e aprovação de Leis municipais visando à construção do muro de arrimo para a proteção contra a erosão causada pelo rio Amazonas na cidade de Parintins datam do final da década de 1950 no Livro de Atas da Terceira Legislatura (1956-1959) da Câmara de vereadores do município. A Lei $n^{\circ} 25$ de 30 de dezembro de 1957, foi um dos primeiros instrumentos legais a entrar em vigor considerando as seguintes determinações:

\footnotetext{
Art. $1^{\circ}$ - Fica aberto o Crédito Especial de Duzentos e Cinquenta Mil Cruzeiros ( $\mathrm{Cr} \$ 250.000,00)$, para ocorrer as despesas do serviço de construção de um muro de Arrimo e aterro, destinado ao ampliamento de um trecho da Rua Rui Barbosa, desta cidade.

Art. $2^{\circ}$ - Os encargos previstos no artigo primeiro $\left(1^{\circ}\right.$.) desta Lei, ocorrerão por conta do saldo do exercício financeiro anterior, de conformidade com que preceitua o artigo 60ํㅡㄹ da Lei n 1, de 3 de janeiro de 1957.
}

A atual e mais ampla estrutura de contenção foi proposta e passou a ser construída por administrações passadas durante as décadas de 70/80. No Livro de Atas da $8^{\underline{a}}$ (1977-1982) e 9a (1983-1988) Legislatura da Câmara Municipal, consta que em agosto de 1980, a SUDAM - Superintendência do Desenvolvimento da Amazônia, em convênio com o DNOS - Departamento Nacional de Obras de Saneamento, liberaram por meio do Banco do Brasil os primeiros recursos no valor de 29 milhões e 505 mil cruzeiros (Cr\$29.505.000,00) para o início dessa obra, que ocorreria em 01 de setembro de 1981, e também para a construção do novo aeroporto da cidade.

Essa estrutura foi inicialmente pensada para atender apenas algumas ruas do Centro da cidade, porém, ao longo dos anos, a mesma foi sendo ampliada de forma fragmentada pelas administrações públicas municipais que se seguiram. Até o ano de 2005, a prefeitura conseguiu, ao estabelecer parceria com o Governo Federal e Estadual, construir partes da extensão do muro de arrimo, o que foi de grande importância para os moradores da cidade, no entanto, a estrutura não chegou a abranger todo o contorno do terraço fluvial da cidade e a erosão continuou a causar diversos problemas.

A extensão do atual muro de arrimo abrange, em sua maior parte, o Centro da Cidade, enquanto que outros bairros que também são atingidos pela erosão lateral possuem estruturas menores. O bairro Santa Clara, localizado no setor jusante da cidade, embora seja o mais afetado pela dinâmica fluvial, não possui estrutura de contenção. Em outros pontos, o muro foi construído pelos referidos proprietários.

No Centro, o muro de arrimo foi construído com fundações superficiais, o que favorece a perda da base de sustentação, assim, a pressão da água atua sobre o pacote sedimentar abaixo da superfície até descalçá-lo e a parte submersa passa a sofrer um contínuo desgaste, favorecendo o abalo por conta do peso excessivo. Essa estrutura de contenção é conhecida na engenharia civil como "muro de gravidade" e por isso não tem fundação armada em profundidade, pois a garantia da estabilidade do sistema vem do peso da estrutura. 
PROCESSOS FLUVIAIS NO RIO AMAZONAS: EROSÃO LATERAL E IMPLICAÇÕES PARA A CIDADE DE PARINTINS

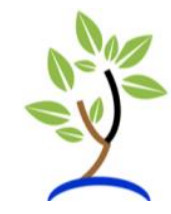

Por toda extensão da margem, o muro de arrimo é constituído em blocos de concreto e que, com o passar do tempo, acabam por se separar pela ação da água do rio e demais intempéries climáticas associadas à variação de temperatura. Observa-se ainda uma deficiência quanto à estrutura do sistema de drenagem do muro, pois não se tem registro da manutenção ou vistoria efetiva desse sistema. A drenagem atua liberando a água que, sobretudo, durante o período chuvoso, exerce um peso significativo dentro da estrutura. Caso o sistema de drenagem possua obstruções que impeçam a saída da água, o muro de arrimo pode sofrer novos pontos de fraturamento.

Em outubro de 2015 a DCP - Defesa Civil de Parintins, enviou um parecer técnico sobre a situação da cidade à Defesa Civil do Estado do Amazonas, no entanto, não obteve resposta, e em função disso a coordenadoria da DCP informou que não há previsão de vistorias ou manutenção no muro de arrimo. A Secretaria Municipal de Obras também confirmou que não há nenhuma previsão para a construção ou reforma do mesmo. As informações que se tem é que propostas nesse sentido já foram encaminhadas para apreciação no Ministério das Cidades, pois o município e o Governo do Estado, não possuem recursos suficientes para a execução desse serviço.

\section{Dificuldades na construção de novas estruturas de contenção}

Embora sejam antigos, os problemas relacionados à erosão lateral do rio Amazonas ainda não foram completamente resolvidos, pois as tentativas de construção de muro de arrimo por parte do poder público esbarram, principalmente, em questões financeiras e de engenharia.

Em setembro de 2009 a Defesa Civil do Estado do Amazonas e a SEINFRA Secretaria de Estado e Infraestrutura, iniciaram uma vistoria técnica no bairro Santa Clara. Na ocasião os referidos órgãos comunicaram que após o término do laudo o muro de arrimo seria erguido e os moradores que precisassem efetuar mudança receberiam indenização. Alguns dias após o anuncio do projeto, os moradores informaram que a obra chegou a ser iniciada, porém foi interrompida e não houve a continuidade do serviço.

No início de 2010 os funcionários da SEINFRA retornaram ao local e realizaram nova avaliação técnica da área, porém a obra não foi retomada. Entre 2011 e 2012 os moradores lembram que a área foi novamente vistoriada, mas nada foi feito, todavia, a pressão popular cresceu, pois algumas famílias passaram a mover ação contra o Estado no Ministério Público para a continuidade da obra e repasse de indenização.

Em 2013 o Governo do Estado divulgou um projeto financiado pelo Ministério da Integração Nacional e assinado pela SEINFRA que previa a construção de dois trechos do muro de arrimo. Para a sua execução, o Governo Estadual apresentou um investimento de aproximadamente $R \$ 8$ milhões, porém, devido a erros de engenharia na planta do projeto a obra não pode ser executada.

Ao iniciar o serviço, a Metacon, uma das empresas vencedora da licitação para a construção da obra, detectou falhas na planta do muro de arrimo da frente da igreja do Sagrado Coração de Jesus - trecho I, e na planta do muro de arrimo da Rua Portugal - trecho II. 
PROCESSOS FLUVIAIS NO RIO AMAZONAS: EROSÃO LATERAL E IMPLICAÇÕES PARA A CIDADE DE PARINTINS

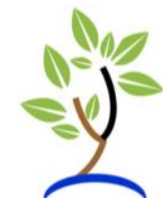

O projeto do trecho I teria uma extensão de 350 metros e foi orçado em $R \$ 3,9$ milhões. A obra não chegou a ser executada, pois quando os engenheiros foram alocar a borda do aterro, o ponto mais distante da estrutura entrava mais de cinco metros dentro do rio Amazonas.

O projeto do trecho II teria 450 metros e o valor do investimento era de $R \$$ 3.902.740,81. Como forma de anuncio, uma placa foi posta na Rua Portugal informando que o início dos trabalhos estava previsto para o dia 02 de maio de 2013, com o prazo de conclusão em 180 dias. Porém, o referido projeto possuía o mesmo erro de engenharia. A falha na planta do projeto impossibilitou o começo das obras, pois, o erro do contorno da borda da estrutura ficava quase 10 metros dentro do rio Amazonas.

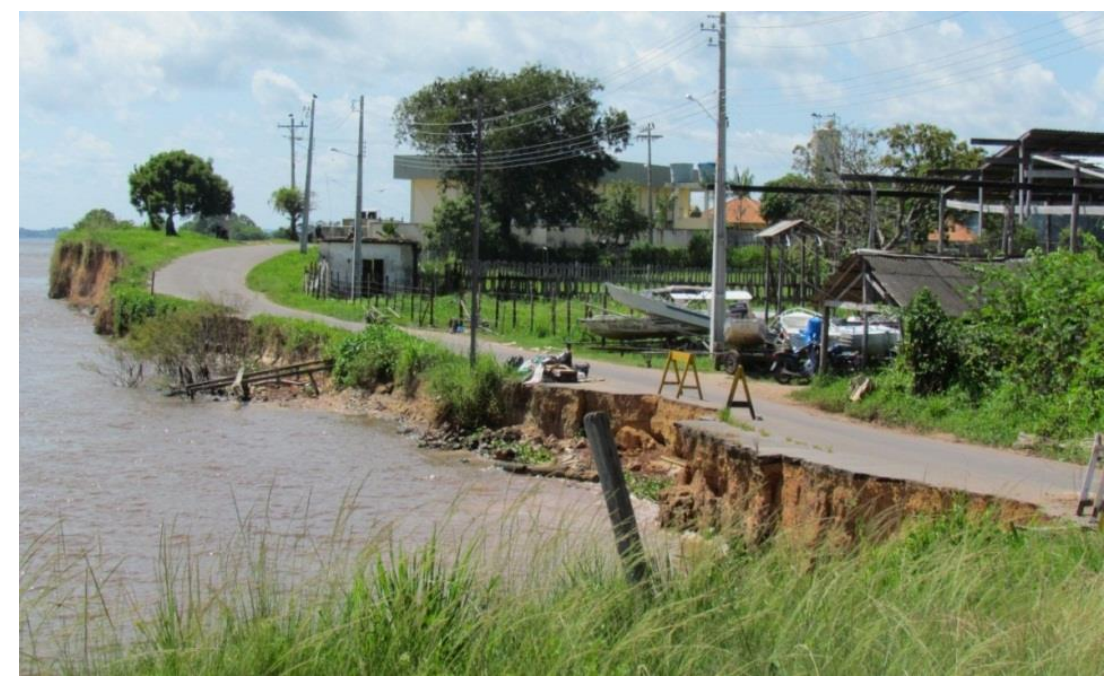

Figura 18. Situação da Rua Portugal em julho de 2011. Foto: SOUZA (2011).

Além do erro de engenharia que inviabilizou o projeto, o tempo previsto para a construção da obra não levaria em consideração a elevação do nível do rio Amazonas, pois no dia 30 do mês de maio de 2013, o rio atingiria a cota máxima registrada no ano $(9,04 \mathrm{~m})$. Mesmo sem a falha na planta do projeto, possivelmente a borda do muro não seria alocada a tempo, visto que após o pico da enchente, o nível do rio Amazonas desceria lentamente e se manteria até dia 23 de julho na cota dos $8 \mathrm{~m}$, e até 17 de agosto na cota dos $7 \mathrm{~m}$, ou seja, com cotas consideradas altas para a execução do serviço.

Outra questão a ser considerada é a distância entre a margem direita e o talvegue do rio Amazonas. Como se observou nas medições batimétricas, o talvegue está sendo encaixado rente a cidade, mostrando que a pressão hidráulica é maior nas proximidades dessa área e que o mesmo está a 662,5 da margem e atingindo profundidade de 80,8 metros, o que facilita o processo erosivo e dificulta qualquer tentativa de obra de engenharia para a contenção do processo.

\section{Principais implicações na vida dos moradores}

a) Perda de propriedade - a diminuição da propriedade causada pela erosão lateral do rio Amazonas é um dos principais problemas vivenciados pelos moradores da cidade de Parintins. A constante perda de terra leva a mudança de residência, isto 
PROCESSOS FLUVIAIS NO RIO AMAZONAS: EROSÃO LATERAL E IMPLICAÇÕES PARA A CIDADE DE PARINTINS

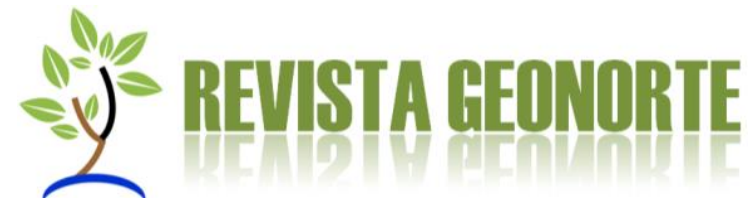

porque em área urbana não há possibilidade de projeção do terreno para o fundo ou da propriedade sem que haja sobreposição fundiária.

Conforme visto anteriormente, o limite inferior, que compreende o bairro Santa Clara, é o mais afetado pela dinâmica fluvial, com áreas recuadas em até 30 metros. $\mathrm{Na}$ Rua Portugal, propriedades já foram totalmente perdidas, enquanto outras sofreram redução a ponto de serem abandonadas pelos moradores.

b) Mudança de residência - em decorrência do risco representado pela erosão lateral do rio Amazonas, o morador muitas vezes precisa abandonar sua antiga moradia pela qual construiu valor simbólico.

Os moradores do bairro Santa Clara que precisaram sair de suas residências por conta da interdição feita em 2009, pela Defesa Civil do Estado, não receberam a indenização que foi assegurada e algumas famílias passaram a morar em casa alugada em outros bairros da cidade.

O laudo preliminar apresentado em março de 2015 como resultado da ação movida pelos moradores contra o Estado, prevê que um valor de aproximadamente $R \$ 1$ milhão seja distribuído entre as sete famílias que possuíam terreno no bairro.

c) Risco à circulação de veículos - a circulação de pessoas próximas aos locais ameaçados pela erosão lateral não representa tanto risco quanto a passagem de veículos de carga, embora seja necessário manter distância para evitar perigo.

A interdição parcial de parte da Rua Caetano Prestes e do trecho final da Rua Armando Prado evitou a circulação de veículos nessas áreas, entretanto outras áreas da cidade merecem atenção devido ao risco causado pela velocidade associada ao peso da carga transportada.

No início da interdição da Rua Caetano Prestes, os bares situados próximo a Praça do Comunas tiveram prejuízos quanto a frequência de clientes, pois estes tinham que deixar seus veículos em locais distantes. No entanto, a interdição feita com cones de concreto para evitar a passagem de veículos logo foi violada e voltou a representar perigo às pessoas que frequentam aquela área da cidade.

A Rua Portugal é a única via que dá acesso ao matadouro frigorífico e também serve como porto para embarcações durante a vazante e por isso é passagem frequente para veículos de carga. A ação combinada entre peso e velocidade ocorre de cima para baixo, deixando instável o pacote sedimentar que já se encontra fragilizado.

Durante o período chuvoso quando o pacote sedimentar está úmido, a água infiltra e enfraquece o solo, e veículos de carga colaboram para o afundamento do terreno, comprometendo a estrutura da via.

d) Risco à navegação - no rio Amazonas a atenção durante a navegação é fundamental dada à quantidade de troncos e galhos de árvore que são transportados pela correnteza após o avanço lateral da erosão. A navegação noturna feita com embarcação de pequeno porte torna o risco de acidente ainda maior, embora acidentes dessa natureza tenham diminuído consideravelmente nos últimos anos. Em Parintins o risco maior é para os barcos atracados na margem.

e) Perda de ruas - assim como em São Paulo de Olivença, Boca do Acre e Careiro da Várzea, a erosão lateral já consumiu parte de algumas ruas da cidade de Parintins, sendo que no bairro Santa Clara uma das principais vias foi reconstruída a 
PROCESSOS FLUVIAIS NO RIO AMAZONAS: EROSÃO LATERAL E IMPLICAÇÕES PARA A CIDADE DE PARINTINS

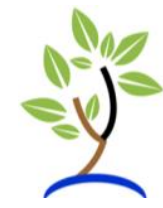

alguns metros em relação à antiga e em terreno particular, porém em poucos anos a mesma já apresenta sua estrutura comprometida.

f) Dificuldade de embarque e desembarque - os locais que se encontram em forma de falésia fluvial ${ }^{3}$ é sempre um problema para quem vai "pegar um barco" ou escoar a produção (CARVALHO, 2006). Em Parintins dois locais merecem atenção: a área em frente ao recinto do porto onde forma uma zona de depósito do rio e que sofre frequente abalo por conta da fragilidade do material; e um trecho da Rua Portugal que é utilizado como porto improvisado durante a vazante. Nessa localidade o acesso ao rio (ou à rua para quem chega à cidade) é feito por meio de uma escada de madeira improvisada e apoiada verticalmente sobre uma falésia de cerca de $8 \mathrm{~m}$ de altura.

De forma resumida, pode-se dizer que a erosão lateral, além das mudanças na paisagem, das perdas materiais e simbólicas e do constante medo psicológico que causa aos moradores, passou a ser um problema que não se limita mais as populações isoladas e dispersas nas margens, por isso necessita de mais estudos para se conhecer as causas e maiores investimentos para minimizar os seus efeitos.

\section{CONSIDERAÇÕES FINAIS}

O processo de erosão lateral atuante na frente da cidade de Parintins envolve uma conjunção de fatores como a pressão hidrodinâmica, condições climáticas, geometria do leito do canal, composição dos sedimentos da margem, localização da cidade em margem côncava e a questão do uso do solo urbano e de políticas públicas. Tal afirmativa permite considerar que é preciso rever alguns fundamentos da geomorfologia fluvial, pois os conceitos encontrados na literatura básica como corrosão, corrasão e cavitação não são suficientes para compreender a complexidade da erosão nas margens do rio Amazonas, conforme também observou Carvalho (2006; 2012).

A posição do talvegue próximo à margem direita, onde está localizada a cidade de Parintins, cuja profundidade chega a 98m, é sem dúvida um dos fatores de maior pressão hidráulica naquela margem, fato que desafia a engenharia em busca de solução. Ainda que seja possível construir uma estrutura que possa conter o avanço do rio por um determinado tempo, o custo financeiro seria muito elevado, o que só é possível com aporte dos governos estadual e federal, pois o município sozinho, possivelmente, não dispõe de recurso para investimento dessa monta.

Com relação às implicações sociais, considera-se que os locais mais vulneráveis à erosão estão localizados na área da Praça do Comunas e adjacências, Centro, e no limite jusante da cidade, área que compreende a extensão marginal do bairro Santa Clara. Verificou-se pelos relatos dos moradores e pelas observações em campo que a erosão lateral tem causado sérios problemas na cidade como o comprometimento da estrutura do muro de arrimo, perda, mudança e desvalorização de propriedades, risco de morte pela proximidade da falésia fluvial, riscos à circulação de veículos, à

\footnotetext{
3 Conceito litorâneo adaptado para a Amazônia para designar margens escarpadas (GUERRA; GUERRA, 2011).
} 
PROCESSOS FLUVIAIS NO RIO AMAZONAS: EROSÃO LATERAL E IMPLICAÇÕES PARA A CIDADE DE PARINTINS

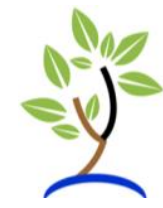

navegação, perda parcial de ruas, perda total de ruas e dificuldade de embarque e desembarque.

Após as questões levantadas, acredita-se ter contribuído para o avanço e ampliação do conhecimento sobre os agentes e mecanismos causadores da erosão lateral e de como esse fenômeno afeta a vida dos moradores da cidade de Parintins. Por se tratar de um processo dinâmico e ainda com poucos estudos, entende-se que a discussão sobre o tema não se encerra nesse artigo e, portanto, faz-se necessário gerar dados e novos conhecimentos para se levantar questões mais profundas que instiguem o debate científico sobre essa dinâmica fluvial.

\section{REFERÊNCIAS}

ANA - Agência Nacional de Águas. Disponível em: hidroweb.ana.gov.br. Acesso em: 25/02/2016.

ANA - Agência Nacional de Águas; CPRM - Companhia de Pesquisas e Recursos Minerais; SIPAM - Sistema de Proteção da Amazônia. Monitoramento hidrológico. Boletim. $n^{\circ} 04-30 / 01 / 2015$.

ANA - Agência Nacional de Águas; CPRM - Companhia de Pesquisas e Recursos Minerais; SIPAM - Sistema de Proteção da Amazônia. Monitoramento hidrológico. Boletim. no $32-22 / 10 / 2010$.

CARVALHO, J. A. L. Erosão nas margens do rio Amazonas: o fenômeno das terras caídas e as implicações na vida dos moradores. 185 p. (Tese de Doutorado. Universidade Federal Fluminense, Programa de Pós-Graduação em GeografiaPPGEO/UFF) Niterói, 2012.

CARVALHO, J. A. L..Terras caídas e consequências sociais: Costa do Miracauera, Paraná da Trindade, município de Itacoatiara-AM. 2006. 142p. Dissertação (Mestrado no Programa de Pós-Graduação Sociedade e Cultura na Amazônia)Instituto de Ciências Humanas e Letras, Universidade Federal do Amazonas, Manaus. 2006.

CHRISTOFOLETTI, A. Geomorfologia fluvial. São Paulo: Edgard Blucher, 1981. vol. 1. $313 \mathrm{p}$.

CPRM - Companhia de Pesquisa e Recursos Minerais. Geodiversidade do Estado do Amazonas. Organização: Maria Adelaide Mansini Maia e José Luiz Marmos. Manaus, 2010.

EMBRAPA - Empresa Brasileira de Pesquisa Agropecuária. Manual de métodos de análises de solo. $2^{\circ}$ ed. Rio de Janeiro, Ministério da Agricultura e do Abastecimento - Centro Nacional de Pesquisa de Solos, 1997. 212 p.

FONTES, L. C. S. Erosão marginal no baixo curso do rio São Francisco: um estudo de caso de impactos geomorfológicos à jusante de grandes barragens. 249 p. (Dissertação. Mestrado em Desenvolvimento e Meio Ambiente. Núcleo de Pós- 
PROCESSOS FLUVIAIS NO RIO AMAZONAS: EROSÃO LATERAL E IMPLICAÇÕES PARA A CIDADE DE PARINTINS

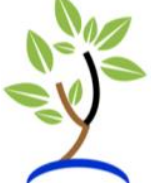

Graduação e Estudos do Semi-Árido, Programa Regional de Pós-Graduação em Desenvolvimento e Meio Ambiente - PRODEMA, Universidade Federal de Sergipe), Aracaju - SE, 2002.

GUERRA, A. J. T; GUERRA, A. T. Novo dicionário Geológico-Geomorfológico. 9ạ Ed. Rio de Janeiro: Bertrand Brasil, 2011.

HIBAM - Hidrologia e Geoquímica da Bacia Amazônica. Relatório das campanhas de medições nos rios Amazonas, Negro, Solimões, Madeira, Trombetas e na Várzea do Lago Grande de Curuai 03/06/2005 - 17/06/2005 (Manaus - Santarém - Várzea de Curuai - Santarém - Manaus).

HIBAM - Hidrologia e Geoquímica da Bacia Amazônica. Relatório das campanhas de medições nos rios Amazonas, Negro, Solimões, Madeira, Trombetas e na Várzea do Lago Grande de Curuai 18/03/2005 - 06/04/2005 (Manaus - Santarém - Várzea de Curuai - Santarém - Manaus).

HIBAM - Hidrologia e Geoquímica da Bacia Amazônica. Relatório das campanhas de medições nos rios Negro, Solimões, Madeira, Amazonas e na Várzea do Lago Grande de Curuai 17/12/2003 - 18/12/2003 (Manaus - Manacapuru - Paricatuba Santarém - Manaus).

HIBAM - Hidrologia e Geoquímica da Bacia Amazônica. Primeira campanha de medições de vazão com ADCP (correntômetro com efeito Doppler) no Rio Amazonas 09/1994. (Manacapuru - Óbidos).

INMET - Instituto Nacional de Meteorologia. Disponível em: www.inmet.gov.br. Acesso em: 25/02/2016.

INPE - Instituto Nacional de Pesquisas Espaciais. Disponível em www.inpe.com,br. Acesso em 26/02/2016.

MEIS, M. R. M. Considerações geomorfológicas sobre o Médio Amazonas. Revista Brasileira de Geografia - IBGE. Rio de Janeiro, 2: 3-20,1968.

PRESS, F. et al. Para entender a Terra. Tradução de Rualdo Meneget. 4. ed. Porto Alegre: Bookman, 2006. 656 p.

TRICART, J. Tipos de planícies aluviais e de leitos fluviais da Amazônia brasileira. Revista Brasileira de Geografia - IBGE. Rio de Janeiro, 1977. p. 3-37.

SUGUIO, K; BIGARELLA, J. J. Ambientes fluviais. Florianópolis, EDUFSC, 1990. $183 \mathrm{p}$.

Recebido em 02/03/2019

Aceito em 01/08/2019 